\title{
EBV reactivation as a target of luteolin to repress NPC tumorigenesis
}

\author{
Chung-Chun Wu ${ }^{1}$, Chih-Yeu Fang ${ }^{1,4}$, Hui-Yu Hsu${ }^{1}$, Hsin-Ying Chuang ${ }^{1}$, Yu-Jhen \\ Cheng $^{1}$, Yen-Ju Chen ${ }^{1}$, Sheng-Ping Chou ${ }^{1}$, Sheng-Yen Huang ${ }^{1}$, Su-Fang Lin ${ }^{1}$, Yao \\ Chang $^{2}$, Ching-Hwa Tsai ${ }^{3}$, Jen-Yang Chen ${ }^{1,3}$ \\ ${ }^{1}$ National Institute of Cancer Research, National Health Research Institutes, Zhunan, Taiwan \\ ${ }^{2}$ National Institute of Infectious Diseases and Vaccinology, National Health Research Institutes, Tainan, Taiwan \\ ${ }^{3}$ Department of Microbiology, College of Medicine, National Taiwan University, Taipei, Taiwan \\ ${ }^{4}$ Department of Pathology, Wan Fang Hospital, Taipei Medical University, Taipei, Taiwan \\ Correspondence to: Jen-Yang Chen, e-mail: cjy@nhri.org.tw \\ Keywords: nasopharyngeal carcinoma, relapse, Epstein-Barr virus, reactivation, Iuteolin
}

Received: September 12, 2015

Accepted: February 08, 2016

Published: March 08, 2016

\section{ABSTRACT}

\begin{abstract}
Nasopharyngeal carcinoma (NPC) is a malignancy derived from the epithelial cells of the nasopharynx. Although a combination of radiotherapy with chemotherapy is effective for therapy, relapse and metastasis after remission remain major causes of mortality. Epstein-Barr virus (EBV) is believed to be one of causes of NPC development. We demonstrated previously that EBV reactivation is important for the carcinogenesis of NPC. We sought, therefore, to determine whether EBV reactivation can be a target for retardation of relapse of NPC. After screening, we found luteolin is able to inhibit EBV reactivation. It inhibited EBV lytic protein expression and repressed the promoter activities of two major immediate-early genes, Zta and Rta. Furthermore, luteolin was shown to reduce genomic instability induced by recurrent EBV reactivation in NPC cells. EBV reactivation-induced NPC cell proliferation and migration, as well as matrigel invasiveness, were also repressed by luteolin treatment. Tumorigenicity in mice, induced by EBV reactivation, was decreased profoundly following luteolin administration. Together, these results suggest that inhibition of EBV reactivation is a novel approach to prevent the relapse of NPC.
\end{abstract}

\section{INTRODUCTION}

Nasopharyngeal carcinoma (NPC) is a malignancy derived from the epithelial cells of the post-nasal cavity and has a unique geographic and ethnic distribution. Although rare worldwide, it is prevalent in areas such as southern China, Southeast Asia, northeast India, North Africa and among the native population of Canada and Alaska. There are an estimated 80,000 new cases per year ( $0.7 \%$ of all cancers), less than 1 per 100,000 globally [1]. The 5 years survival rate is $60 \%$; treatment at early stages of disease leads to a good 5-year survival rate (80$95 \%$ ) but not for late stage disease (40-50\%). NPC is markedly radiosensitive and radiotherapy is the primary mode of treatment; however, chemoradiotherapy has been shown to be superior to radiotherapy alone for advanced NPC patients [2]. Recently, with the improvement in combination of radiotherapy provided by neoadjuvant chemotherapy, the survival rate has increased significantly [3-5]. However, relapse and metastasis after remission remain major causes of mortality. Prevention of relapse and metastasis seems to be the most important issue in the study of NPC.

$\mathrm{EBV}$, a member of the herpesviruses, has a linear double-stranded DNA genome of around $170 \mathrm{~kb}$. The replication cycle includes latent and lytic stages and the switch from latency to the lytic cycle is known as reactivation $[6,7]$. EBNAs 1, 2, 3A, 3B, 3C and LP and LMPs 1, 2A and $2 \mathrm{~B}$ are expressed during latency. Upon reactivation to the lytic cycle, the immediate early genes Zta and Rta are expressed first, followed by the early genes (DNase, DNA polymerase, thymidine kinase, etc.) and late genes (VCA and MA, etc) [8]. Elevation of antibodies against EBV lytic gene products has been considered as a marker of EBV reactivation in vivo [9-11]. The infection is ubiquitous in most human populations, with no obvious symptoms. This virus has been 
shown to be the etiological agent of infectious mononucleosis and is associated with many human malignancies, including African Burkitt's lymphoma and NPC [8].

EBV infection, consumption of nitroso-compounds and genetic factors are considered to play important roles in the carcinogenesis of NPC $[12,13]$. Elevation of antibodies against EBV in NPC patients and the presence of the EBV genome and expression of EBV genes in NPC tissues indicate the close association of EBV infection with NPC [14-20]. Individuals with higher levels of antibodies against EBV tend to have a high risk of NPC development [19]. Recent epidemiological studies indicated that fluctuation of antibodies to EBV occurs prior to the onset of NPC [21, 22]. These results suggest that EBV may contribute to the initiation of NPC. To elucidate the role of EBV in the initiation of NPC, a model system of EBV infection and reactivation in normal nasopharyngeal epithelial cells is required urgently. Unfortunately, there is no such model system available at this time.

Through years of studies, it was proposed that latent $\mathrm{EBV}$ infection contributes to the development of NPC after the high grade pre-invasive dysplasia [23]. Among the EBV latent proteins, latent membrane protein 1 (LMP1) is considered to make the most significant contribution to the development of NPC. In addition to the induction of genome instability [24-27], it has been shown that LMP1 induces matrix metalloproteinase 1 to increase metastasis, and interleukin-8 to increase angiogenesis, of NPC [28-30]. One of the most interesting features is that LMP1 induces hypoxia-inducible factor $1 \alpha$ (HIF1- $\alpha)$ and this subsequently contributes to the increased expression of vascular endothelial growth factor (VEGF) [31]. Further study indicated the up-regulation of HIF $1 \alpha$ is through Siah1 to down-regulate prolyl hydroxylases 1 and 3 [32]. More strikingly, LMP1 was found to promote NPC progression through increased levels of HIF $1 \alpha$ in the exosomes of NPC cells [33]. The pathogenic role of LMP1 in NPC has been reviewed recently [34].

In our laboratory, we have established the EBVpositive NPC cell lines, NA and HA [35] from the EBVnegative NPC line TW01, derived from an NPC patient in Taiwan [36]. Because most NPC can be treated with remission by radio-chemotherapy, NA, HA and TW01 cells are considered as residual EBV-positive and negative NPC cells after remission and may be informative regarding the relapse of NPC. Using these cells as a model system, we could investigate the role of EBV infection in the carcinogenesis of NPC cells.

Genomic instability is one of the hallmarks of cancer [37]. We found that recurrent EBV reactivation contributes much more profoundly than latent infection to the genomic instability and tumorigenesis of NPC cells [38]. We demonstrated further that the expression of EBV lytic genes contributes to the genomic instability of NPC cells [39-41]. In particular, recurrent expression of BALF3, a homologue of terminase, does not induce cytotoxicity but mediates genomic instability and progressive malignancy
[41]. These results suggest the importance of lytic infection, probably abortive, for the relapse of NPC. We therefore asked whether EBV reactivation can be a target for the prevention or retardation of relapse of NPC.

Recently the "nutraceutical" concept has become prominent. Scientific evidence has shown that vegetables and fruits contain phytochemicals, such as polyphenols, terpenes and alkaloids, that may provide substantial health benefits, other than basic nutrition [42]. Epidemiological studies indicate that populations that consume foods rich in vegetables and fruits have a lower incidence of cancers [43]. Lycopenes from tomatoes and vitamin $\mathrm{D}$ have been shown to be useful for the treatment of prostate cancers [44-46]. Histone deacetylase (HDAC) inhibitors are also considered as potential cancer therapeutic agents and some are the subjects of clinical trials [47]. In a region of China with a high-risk for NPC, inhabitants living in a particular area with a low NPC prevalence have a lower potential for endogenous nitrosation, suggesting the presence of nitrosation inhibitors in their diet [48]. It is worthwhile to seek more and better natural products for NPC prevention. These results led us to look for natural compounds which may prevent EBV reactivation in NPC cells in order to find dietary supplements which may be useful for the prevention of EBV reactivation and subsequent NPC relapse after remission.

After extensive screening, we focused on luteolin, a member of a group of dietary flavonoids found abundantly in medicinal herbs, fruits and vegetables (e.g. parsley, green peppers, citrus, celery and chamomile). Luteolin is known to be a good free radical scavenger and inducer of tumor apoptosis [49] and also has valuable effects in cancer prevention and therapies [50]. It has been reported to have good effects in anti-angiogenesis, anti-metastasis, antiinflammation and estrogenic regulation, and to regulate many signaling pathways $[51,52]$. However, although a few studies have been published, the question whether luteolin has anti-viral activity is less well understood [53, 54].

In this study, using the NPC cell lines NA and HA, luteolin is shown to inhibit EBV reactivation significantly by suppressing the promoter activities of two immediate-early genes, Zta and Rta. Furthermore, we found that luteolin treatment not only suppressed EBV reactivation but also reduced genomic instability and repressed the tumorigenic features induced by repeated EBV reactivation in vitro and in vivo, suggesting that inhibition of EBV reactivation is a novel target to overcome the relapse of NPC.

\section{RESULTS}

\section{The cytotoxicity of luteolin to NPC cells, determined by WST-1 assay}

Luteolin is a flavone with a classic flavonoid 2-phenylchromene-4-one ring structure (Figure 1). NA and another EBV-infected NPC cell line, HA, were used to address the question whether luteolin can inhibit EBV lytic reactivation. First, we sought to determine 
the cytotoxicity of luteolin to NA, HA and their parental TW01 and HONE-1 cells, to rule out any effect of cellular toxicity. Each cell line was cultured in 96-well plates and, after plating, various concentrations of luteolin were administered for $24 \mathrm{hr}$ or $48 \mathrm{hr}$ to determine its cytotoxicity by WST-1 assay. The values of half maximum of cytotoxicity concentration $50\left(\mathrm{CC}_{50}\right)$ for $48 \mathrm{hr}$ treatment of NA and TW01 were 124 and $115 \mu \mathrm{M}$, while the values for HA and HONE-1 were $78 \mu \mathrm{M}$ and $68 \mu \mathrm{M}$ (data not shown). Taken together, we determined that the $\mathrm{CC}_{50}$ value of luteolin was 68 to $272 \mu \mathrm{M}$ for 24 and $48 \mathrm{hrs}$, which is similar to that in other epithelial cancer cells $[54,55]$. Thus we chose $1 \sim 50 \mu \mathrm{M}$ as our working concentrations for further studies.

\section{Luteolin inhibits the expression of EBV lytic proteins}

After induction or stimulation, the first lytic EBV proteins to be expressed are the immediate early proteins, Zta and Rta, followed by numerous early and late proteins, and subsequently the release of infectious virions. To investigate whether luteolin induces EBV into the lytic cycle, NA cells were plated for $24 \mathrm{hr}$ and then the cells were treated with various concentrations of luteolin. After 25 or $49 \mathrm{hr}$, cell extracts were harvested for western analysis. As expected, luteolin did not induce expression of the lytic proteins Zta, Rta, EAD and DNase after treatment for 25 and $49 \mathrm{hr}$, shown in the left panels of Figure 2a, suggesting<smiles>O=c1cc(-c2ccc(O)c(O)c2)oc2cc(O)cc(O)c12</smiles>

Figure 1: The chemical structure of luteolin.

(a)NA

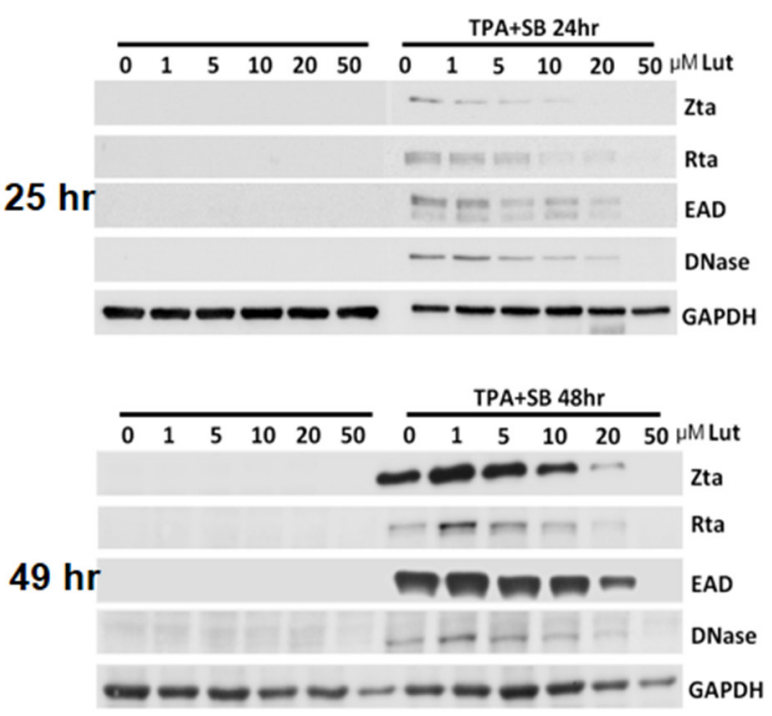

(b) $\mathrm{HA}$

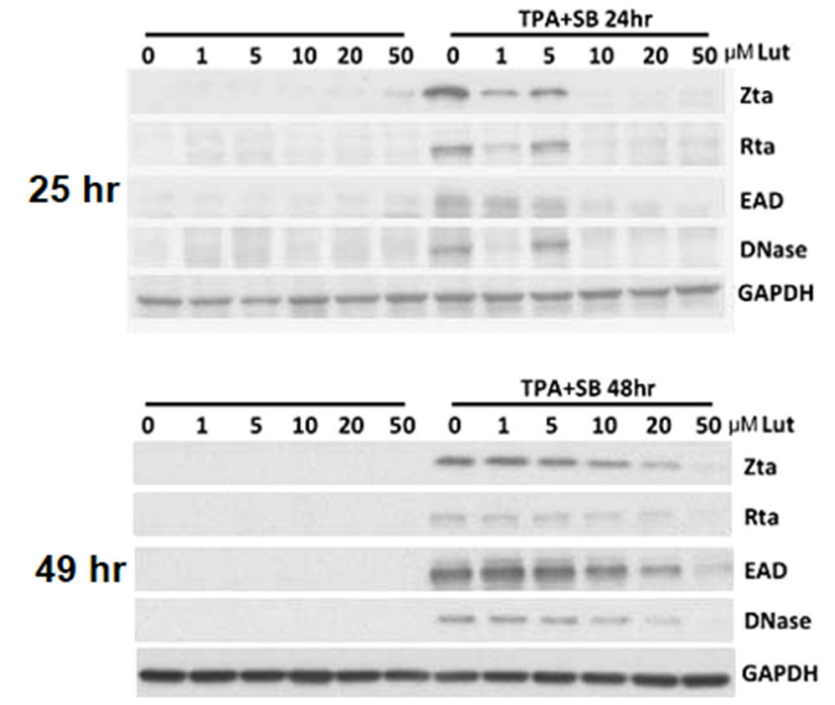

Figure 2: Luteolin inhibits expression of EBV lytic proteins in EBV-positive cells. Epithelial cells NA a. and HA b. were subjected to western blotting. Various concentrations of luteolin were added to the cells for $25 \mathrm{hr}$ to detect enhancement of reactivation. Cell lysates were collected for western blotting. For detection of inhibition of reactivation, the cells were pre-treated with various concentrations of luteolin for $1 \mathrm{hr}$, then TPA (40 ng/ml) and SB ( $3 \mathrm{mM})$ co-treatment was used for EBV induction. After 24 and $48 \mathrm{hr}$ of incubation, cell lysates were analyzed by western blotting with antibodies against EBV Zta, Rta, EAD, DNase and GAPDH. 
that it could not induce the EBV lytic cycle in NA cells. To avoid the possibility of cell specificity, another EBVpositive cell line, HA, was examined using the same procedure and with a similar result: luteolin treatment also did not induce EBV reactivation in HA cells (left panels, Figure 2b). Next, we tried to determine whether luteolin can block EBV reactivation from latency. For NA and HA cells, $\mathrm{TPA}+\mathrm{SB}$ (TS) treatment is a common inducer of EBV lytic reactivation and can activate EBV effectively and induce significant expression of lytic proteins [35]. Moreover, detection of lytic protein expression is a sensitive method for evaluating EBV reactivation [35]. In order to ensure more effective luteolin treatment, NA and HA cells were pre-incubated with various concentrations of luteolin for 1 $\mathrm{hr}$ prior to treatment with TPA $(40 \mathrm{ng} / \mathrm{ml})$ and SB $(3 \mathrm{mM})$. After further incubation for 24 or $48 \mathrm{hr}$, cell extracts were collected for the detection of lytic proteins by western blot analysis. As shown in the right-hand panels of Figure 2a, $\mathrm{TPA}+\mathrm{SB}$ treatment induced the expression of the EBV lytic proteins Zta, Rta, EAD and DNase without luteolin treatment. Meanwhile, the expression of EBV lytic proteins was reduced slightly following treatment with 1 and 5 $\mu \mathrm{M}$ luteolin for 24 and $48 \mathrm{hr}$ induction, and decreased significantly with $5 \mu \mathrm{M}$ luteolin for $24 \mathrm{hr}$ and $10 \mu \mathrm{M}$ for $48 \mathrm{hr}$ induction. Lytic protein expression was undetectable following treatment with 20 and $50 \mu \mathrm{M}$ luteolin for 24 and $48 \mathrm{hr}$ after induction (Figure 2a). In HA cells, luteolin inhibited lytic protein expression significantly with $10 \mu \mathrm{M}$ treatment for $24 \mathrm{hr}$ and $50 \mu \mathrm{M}$ for $48 \mathrm{hr}$, which were higher concentrations than used for the treatment of NA cells (right panels, Figure 2b). Luteolin inhibited all detectable EBV lytic protein expression completely at $50 \mu \mathrm{M}$, which was similar to the treatment of NA cells (right panels, Figure 2b). Similarly, luteolin had an inhibitory effect on the expression of EBV lytic proteins after induction in C666-1 cells (Supplementary Figure S1a). Taken together, these results suggest that the flavonoid luteolin cannot induce EBV into the lytic cycle but, rather, inhibited EBV entry into the lytic cycle in EBV-positive cells.

\section{Luteolin decreases the populations of EAD- expressing cells, monitored by flow cytometric analysis}

Next, we examined the inhibition of EBV lytic reactivation by luteolin and detected EAD expression in NA and HA cells using flow cytometric analysis after luteolin treatment, with and without TS induction. NA and HA cells were pre-treated with various concentrations of luteolin for $1 \mathrm{hr}$, then co-treated with TPA (40 ng/ml)/SB (3 mM). After $48 \mathrm{hr}$ induction, the cells were collected for detection of EAD by flow cytometric analysis. The percentage of EAD expressing cells was estimated to determine the amount of EBV lytic reactivation. For NA cells with $48 \mathrm{hr}$ induction by TS, the population of EADpositive cells was $52 \%$ without luteolin treatment, while it was $25 \%$ and $8 \%$ after treatment with $10 \mu \mathrm{M}$ and 20 $\mu \mathrm{M}$ luteolin, respectively (Figure 3a). Meanwhile, 50\% (a) NA
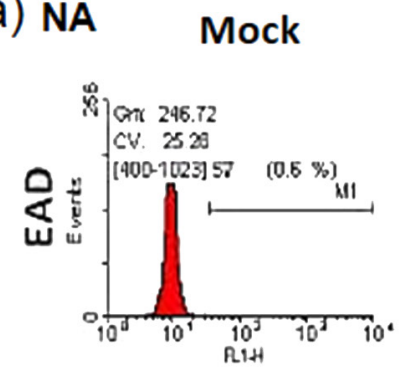

(b)

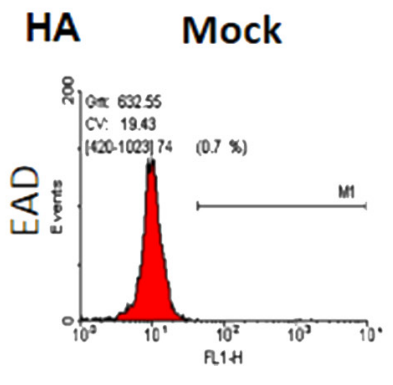

TS

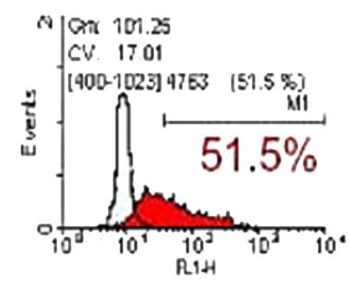

TS

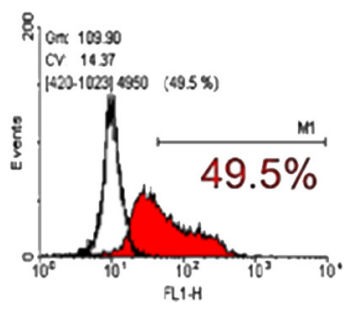

TS-Lut10 $\mu \mathrm{M}$

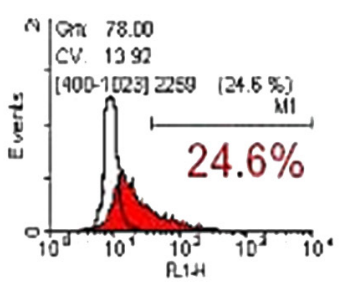

TS-Lut10 $\mu \mathrm{M}$

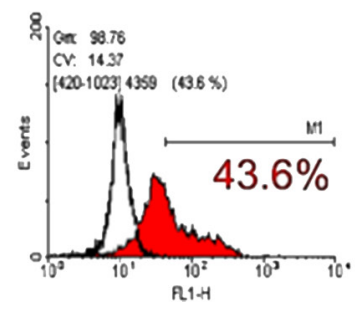

\section{TS-Lut20 $\mu \mathrm{M}$}

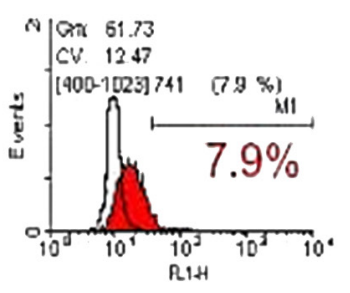

\section{TS-Lut20 $\mu \mathrm{M}$}

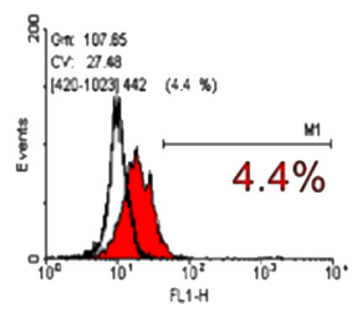

Figure 3: Luteolin decreases the populations of EAD-expressing cells. NA a. and HA b. cells were processed for flow cytometric analysis. For detection of reactivation inhibition, the cells were pre-treated with various concentrations of luteolin for $1 \mathrm{hr}$, then TPA $(40 \mathrm{ng} / \mathrm{ml})$ and SB $(3 \mathrm{mM})$ were added for EBV induction. After $24 \mathrm{hr}$ of incubation, the cells were analyzed by flow cytometry with antibody against EBV EAD. TS: TPA+SB; TS-Lut10 $\mu \mathrm{M}$ : TPA+SB+luteolin $(10 \mu \mathrm{M})$; TS-Lut20 $\mu \mathrm{M}$ : TPA+SB+luteolin $(20 \mu \mathrm{M})$. 
of HA cells expressed EAD after TS induction without luteolin treatment (Figure 3b), lower than NA cells (52\%). The percentages of HA cells expressing EAD were $44 \%$ and $4 \%$ following treatment with 10 and $20 \mu \mathrm{M}$ luteolin, respectively (Figure $3 \mathrm{~b}$ ). These results provide further evidence that luteolin can inhibit the EBV lytic cycle.

\section{Luteolin represses the transcriptional activities of $\mathrm{Zp}$ and $\mathrm{Rp}$}

Because the activities of the Zta and Rta promoters (Zp and $\mathrm{Rp}$ ) are crucial for initiation of the EBV lytic cycle, we sought to determine whether luteolin can inhibit their transcriptional activities using a transient transfection assay. NA cells were transfected with Zp (pZp-Luc) or $\mathrm{Rp}$ (pRp-Luc) firefly luciferase reporter plasmid for 3 hr. Subsequently, the cells were treated with various amounts of luteolin for $1 \mathrm{hr}$ followed by TS induction for $24 \mathrm{hr}$. Luciferase activity was subsequently determined as described in Material and Methods. As expected, for the positive control, the luciferase activities of $\mathrm{Zp}$ and $\mathrm{Rp}$ both increased over 15-fold after TS induction, compared to the mock-transfected control (Figure 4a, upper panel, 0 $\mu \mathrm{M})$. At the same time, the luciferase activities of $\mathrm{Zp}$ and Rp were gradually repressed by increasing concentrations of luteolin (Figure 4a, upper panel). Co-treatment with TS and $50 \mu \mathrm{M}$ luteolin reduced the activities of $\mathrm{Zp}$ and $\mathrm{Rp}$ to the mock-transfected control level, meanwhile, transfection of NA cells with the empty vector PGL2 showed that all values were at background levels (Figure 4a, upper panel).

Furthermore, we used SB alone to induce EBV reactivation and tried to analyze this phenomenon in detail. For SB induction, the result was that SB-induced $\mathrm{Zp}$ and $\mathrm{Rp}$ activities were similar to induction by TS (Figure 4a, lower panel, $0 \mu \mathrm{M}$ ). Even so, luteolin repressed $\mathrm{Zp}$ and $\mathrm{Rp}$ activities gradually with increasing concentrations (Figure 4a, lower panel, 0-50 $\mu \mathrm{M}$ ), compared to the mock control, following SB induction.

To avoid the influence of endogenous EBV in NA cells, we used the parental TW01 cells for the analysis, as described above. The relative folds of $\mathrm{Zp}$ and $\mathrm{Rp}$ activities were lower than those in NA cells following TS induction (Figure 4b). Similarly, regardless of the treatment (TS or SB), luciferase activities of Zp and Rp were repressed gradually by increasing concentrations of luteolin (Figure 4b), suggesting that luteolin can inhibit Zp and $\mathrm{Rp}$ activities following chemical induction.

\section{Inhibition of recurrent $\mathrm{EBV}$ reactivation by luteolin decreased reactivation-induced genomic instability in NA cells}

EBV reactivation has been shown to be important for tumorigenesis. In our previous study, we showed that recurrent $\mathrm{EBV}$ reactivation leads to more profound genomic instability and tumorigenesis than seen during EBV latency, implying that EBV reactivation may be (a)

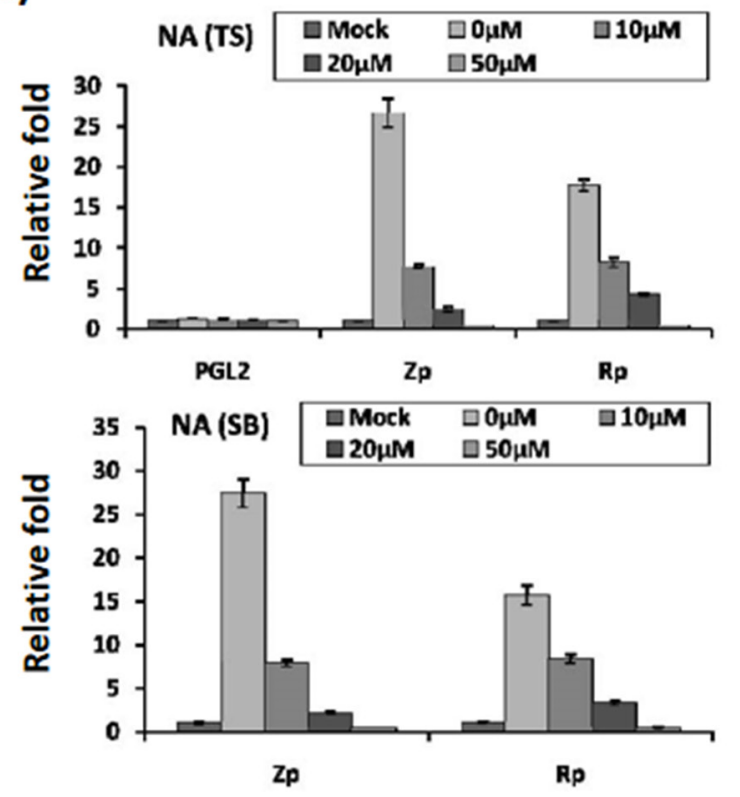

(b)

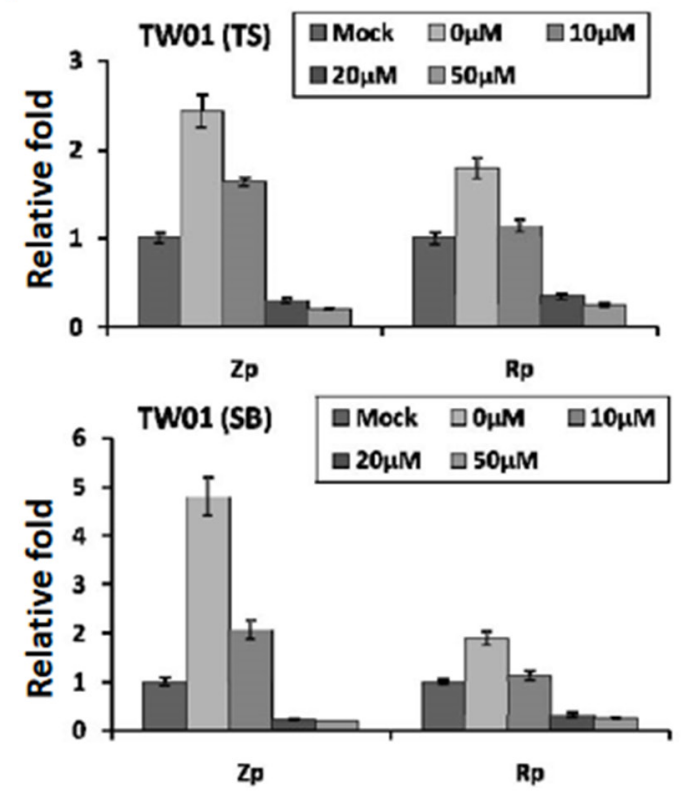

Figure 4: Luteolin represses $\mathrm{Zp}$ and $\mathrm{Rp}$ activities stimulated by chemical inducers. Control plasmid PGL2, Zp, or Rp was transfected into NA cells a. and the parental cell line TW01 b. After 3 4 hr of transfection, luteolin was added or not for pre-treatment for $1 \mathrm{hr}$, and then different methods (TS(TPA+SB) and SB only) were used to induce EBV into the lytic cycle. After induction for $24 \mathrm{hr}$, cells lysates were collected for measurement of luciferase activity. The mean and standard deviation of each sample was calculated based on duplicates from at least two independent experiments. 
a potential target against tumorigenesis [38, 56]. Based on these observations, we postulated that inhibition of the EBV lytic reactivation by luteolin could repress reactivation-induced genomic instability and malignancy. To test this hypothesis, we modified the culture system to carry out repeated reactivation combined with luteolin administration to examine the impact of inhibition of EBV reactivation on genomic instability and the malignant characteristics of NA cells (Figure 5). The EBV-positive cell line NA and its parental EBV-negative cell line TW01 were included in parallel to compare the effects between treatment with inducers (TS) alone (in TW01 cells) and chemical-induced EBV reactivation (in NA cells). MN formation was determined for the alteration of genomic instability. As shown in Figure 6a, TW01 cells after one passage (TW01-P1) with $20 \mu$ l luteolin treatment did not increase the extent of $\mathrm{MN}$ formation. If the cells in the TW01-P1 group were treated with TS, slightly increased formation of MN was observed; however, no significant difference could be detected in the extent of MN formation under TS and luteolin co-treatment (Figure 6a). On the other hand, in EBV-positive NA cells after one passage (NA-P1), although luteolin alone did not inhibit the formation of $\mathrm{MN}$, it repressed TS-induced $\mathrm{MN}$ formation in a dose-dependent manner (Figure 6a). In the TW01 cells after 10 passages (TW01-P10), similar to the TW01-P1 group, low levels of MN formation occurred, regardless of the types of chemical treatment (Figure 6b).
This result indicated that, without the impact of EBV, a subtle increase in MN formation was induced in NPC cells following TS treatment, which was similar to our previous observations $[38,56]$. Moreover, NA cells after 10 passages with TS treatment (NA-P10) exhibited a more profound increase than the NA-P1 group in terms of the formation of $\mathrm{MN}$, revealing that recurrent $\mathrm{EBV}$ reactivation caused accumulation of $\mathrm{MN}$, compared to the mock control (Figure 6b). Furthermore, increasing amounts of luteolin could repress the formation of $\mathrm{MN}$ gradually, in both the NA-P1 and NA-P10 groups (Figure 6b). Similarly, luteolin inhibited MN formation after TS induction in C666-1 cells and HA cells (Supplementary Figures S1b and S1d). These results suggest that luteolin can effectively repress the formation of $\mathrm{MN}$ induced by EBV reactivation.

\section{Luteolin inhibits cell proliferation induced by recurrent $\mathrm{EBV}$ reactivation}

An increase in cell proliferation is a common feature of carcinogenic cells. To determine whether luteolin can suppress cell proliferation triggered by recurrent EBV reactivation, a WST-1 assay was performed to detect the survival rate of NA and TW01 cells treated by repeated TS induction, without or with luteolin. For NA cells, the TS treatment group exhibited accelerated cell proliferation compared to the mock control; however, this decreased

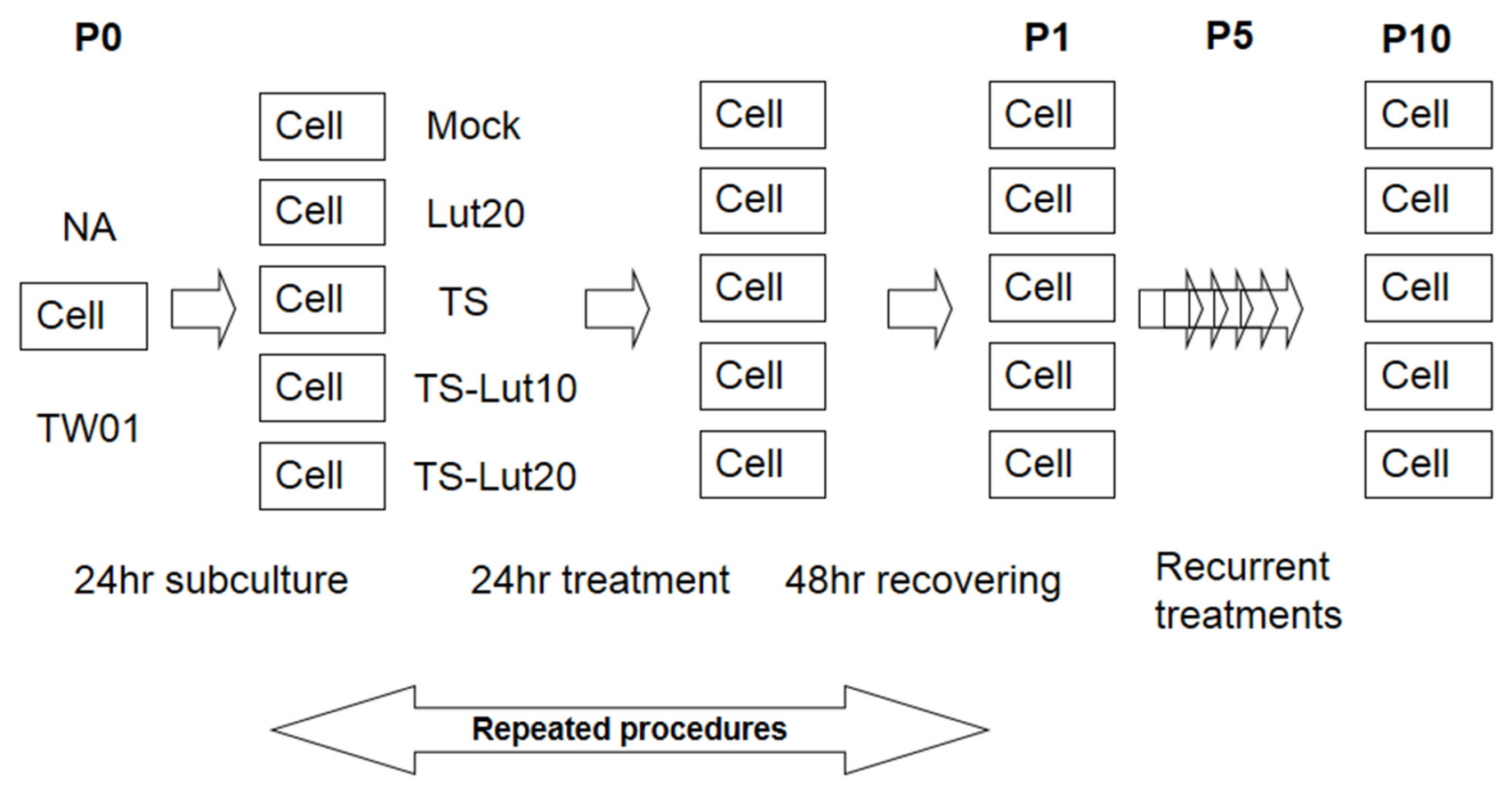

Figure 5: Representative illustration of recurrent chemical treatment of NPC cells. Cells were mock or treated repeatedly with the chemicals indicated. The cells at the beginning of this procedure were defined as passage 0 cells (P0). After seeding, the cells were treated with luteolin for $1 \mathrm{hr}$ or not, followed by treatment with TPA $(40 \mathrm{ng} / \mathrm{ml})$ and SB (3 mM). After incubation for $24 \mathrm{hr}$, the cells were allowed to recover by incubation with fresh medium for a further $48 \mathrm{hr}$. These resulting cells were defined as passage $1 \mathrm{cells}$ (P1). The procedure was repeated for 10 times. "Pn" represents treated NPC cells, where n means the passage number of the cells. TS, Lut10 and Lut20 indicate cells treated with TPA+SB, luteolin $10 \mu \mathrm{M}$ and luteolin $20 \mu \mathrm{M}$. 
gradually with luteolin treatment (Figure 7a). On the other hand, there was no obvious change among the groups of TW01 cells (Figure 7b). These results suggested that luteolin can inhibit cell proliferation induced by repeated EBV reactivation.

\section{The tumorigenic properties of NPC cells, induced by $\mathrm{EBV}$ reactivation, were repressed with luteolin treatment}

In addition to genomic instability, EBV reactivation increased a number of tumorigenic properties in NPC cells, including cell migration, cell invasion and spheroid formation [57]. To determine whether luteolin could inhibit these malignant properties of NPC cells, repeated EBV reactivation was carried out without and with luteolin treatment for analysis of the tumorigenic phenotypes, including cell migration, cell invasion and spheroid formation. EBV-positive NA cells under recurrent TS induction were subjected to cell migration assays and the degrees of migration increased significantly compared to the mock control, however, this decreased following treatment with luteolin (Figure $8 \mathrm{a}$ and $8 \mathrm{~b}$ ). This migration inhibition was not seen in TW01 cells treated with luteolin (Figure $8 \mathrm{a}$ and $8 \mathrm{~b}$ ). In addition, invasion of NA cells was accelerated in the group undergoing repeated TS induction and this was repressed when luteolin was added (Figure 9a and 9b). This inhibition of invasion also was not seen using TW01 cells treated with luteolin (Figure 9a and 9b).
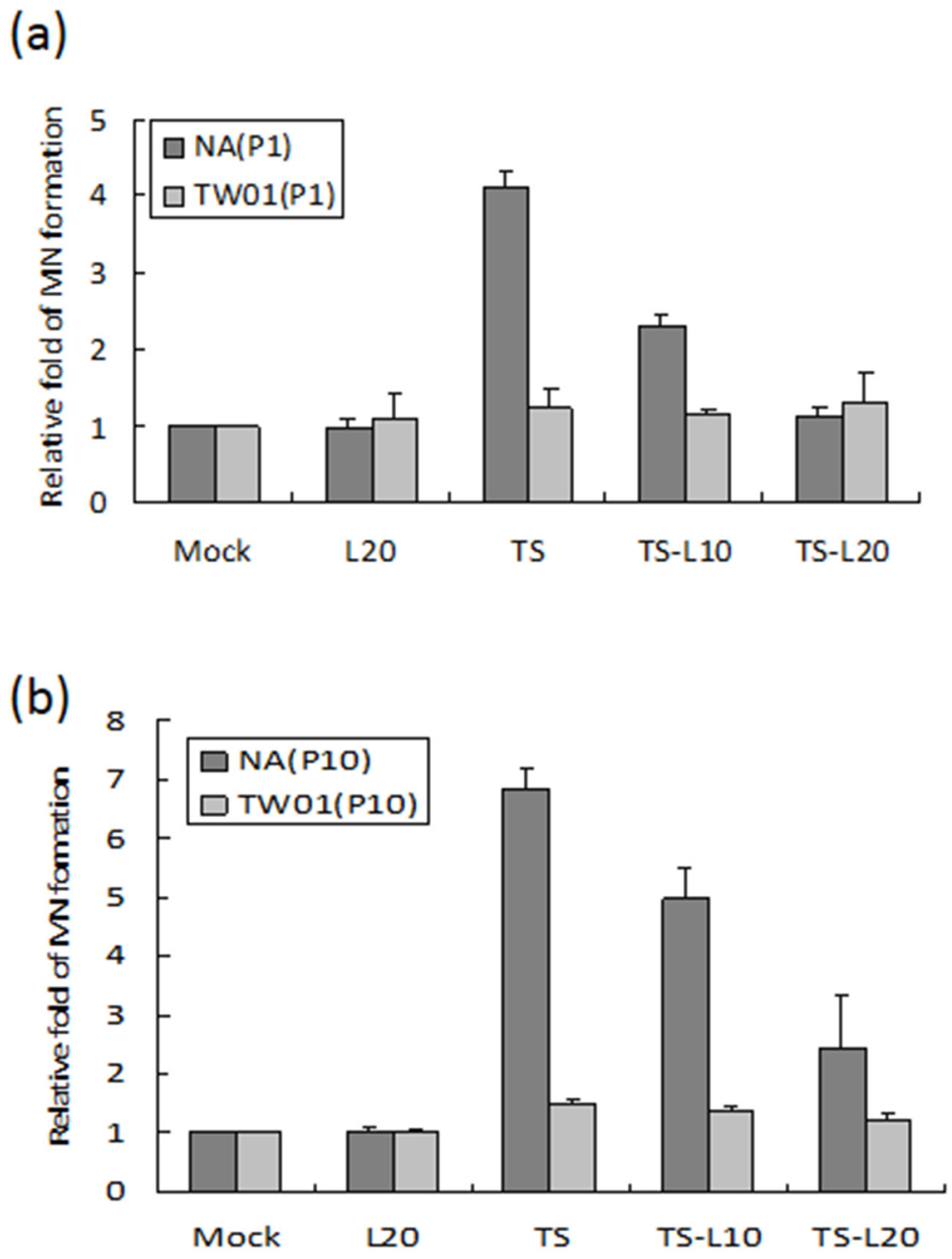

Figure 6: Luteolin inhibits reactivation-induced MN formation. The EBV-positive cell line NA and its parental EBV-negative cell line, TW01, with different times of chemical treatment were included in parallel to compare the effects of formation of MN. Cells after a. one passage (P1) and b. ten passages (P10) treatments were harvested and stained with Hoechst 33258 for MN examination using fluorescence microscope. In all results, the values are a mean $\pm \mathrm{SD}$ from at least three separate experiments. L20: luteolin $20 \mu \mathrm{M}$; TS: TPA+SB; TS-L10: TPA+SB+luteolin $(10 \mu \mathrm{M})$; TS-L20: TPA+SB+luteolin $(20 \mu \mathrm{M})$. 
Cancer cells are present in three-dimensional structures in vivo. The formation of multicellular spheroids mimics a tissue-like architecture and exhibits cell-cell contact with intercellular adhesion. Here, in our spheroid formation assay, the TS-treated NA cells formed larger spheroids than the mock control but spheroid formation was repressed after addition of luteolin. However, a similar phenomenon could not be demonstrated in TW01 cells (Figure 10a and 10b). Interestingly, little inhibition of migration and invasiveness was detectable in NA and TW01 cells treated with luteolin alone but this effect was not statically significant (Figures 8 and 9).

\section{Inhibition of EBV reactivation by luteolin} represses tumor growth in a mouse model

Based on the observation that treatment with luteolin dramatically decreased the tumorigenic properties of NPC cells, induced by recurrent EBV reactivation, we sought to determine whether luteolin repressed tumor growth induced by repeated EBV reactivation in a mouse model (Figure 11a). We first tried to establish the mouse model of EBV reactivation with chemical induction in NA cells. NA cells ( $2 \times 10^{6}$ cells) were inoculated subcutaneously into SCID mice. After tumor appearance

\section{(a)NA}

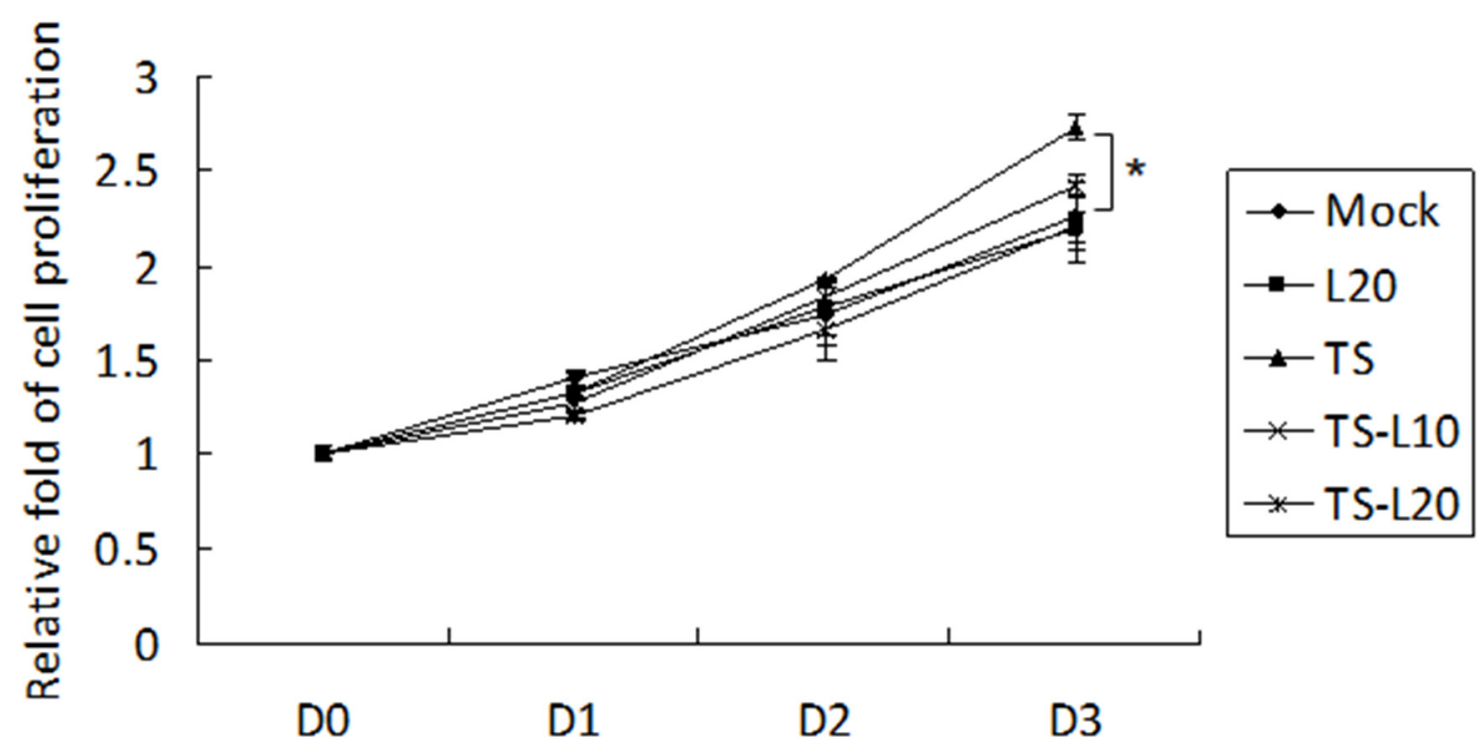

(b)TW01

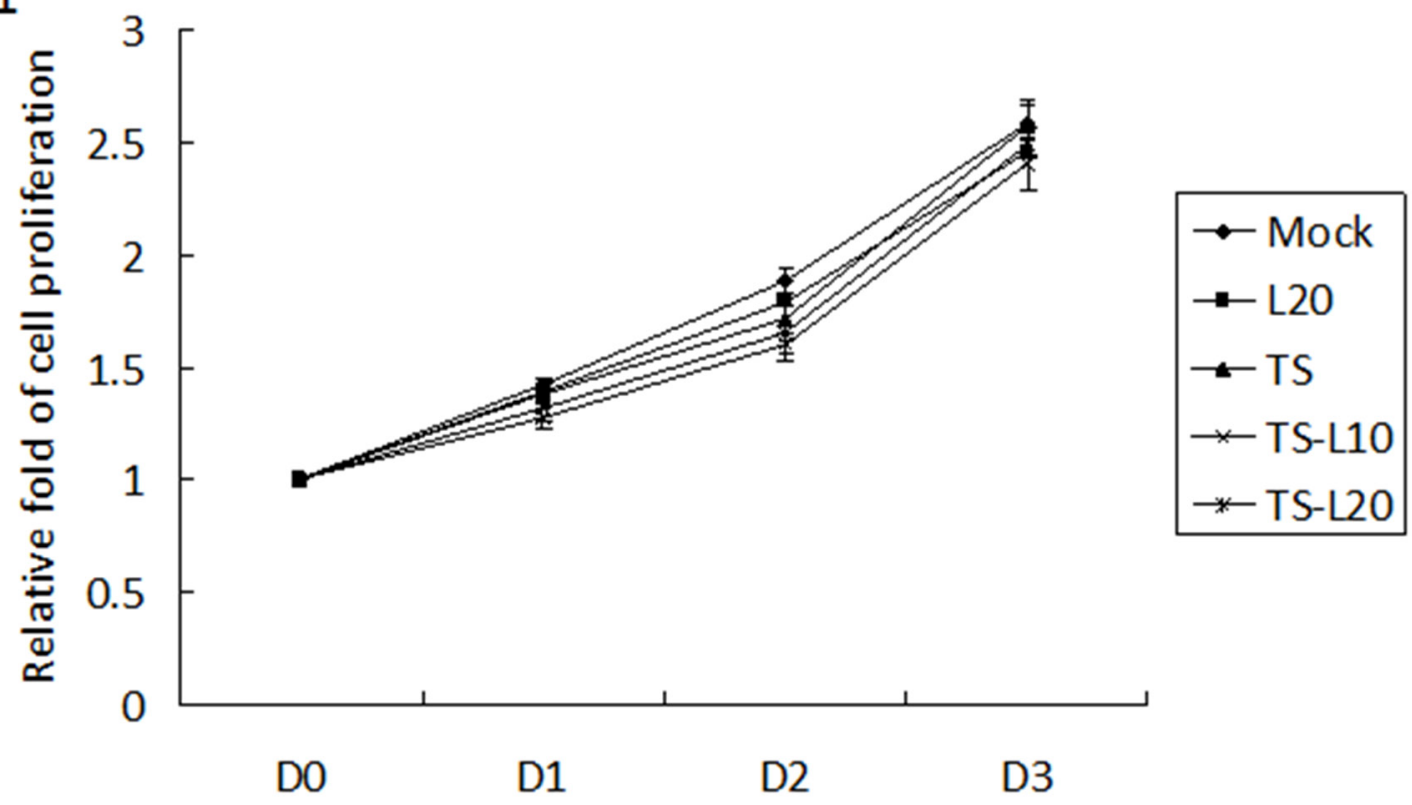

Figure 7: Luteolin represses reactivation-induced cell proliferation. $\mathbf{a}$. NA and $\mathbf{b}$. TW01 cells under repeated treatment were subjected to WST-1 assay to detect the tendency for cell proliferation. In all results, the values are a mean \pm SD from at least three separate experiments. *: p<0.05. L20: luteolin $20 \mu \mathrm{M}$; TS: TPA+SB; TS-L10: TPA+SB+luteolin (10 $\mu \mathrm{M})$; TS-L20: TPA+SB+luteolin (20 $\mu \mathrm{M})$. 
for 4 weeks, the mice were separated into several groups and SB, SB+luteolin, TS and TS+luteolin were administered intraperitoneally every 3 or 4 days (Figure 11a). The tumors were harvested after two further weeks of development and analyzed for Zta and EAD expression to detect EBV reactivation. With no obvious toxicity in terms of mouse body weights (Figure 11b), the tumors from SB and TS-treated mice had significant expression of EBV lytic proteins; however, protein expression was repressed in the luteolin-treated mice (Figure 11c). After successful establishment of the mouse model of EBV reactivation, tumorigenicity experiments were carried out to determine whether luteolin could repress reactivationinduced tumor growth. NA and TW01 cells $\left(2 \times 10^{6}\right.$ cells $)$ were inoculated subcutaneously into SCID mice. After tumor appearance, mice implanted with NA and TW01 cells were separated into several groups and were injected intraperitoneally with mock-treatment (water control), SB or SB+luteolin every 3 or 4 days, as described above (Figure 11a). The tumors were harvested after two further

(a)

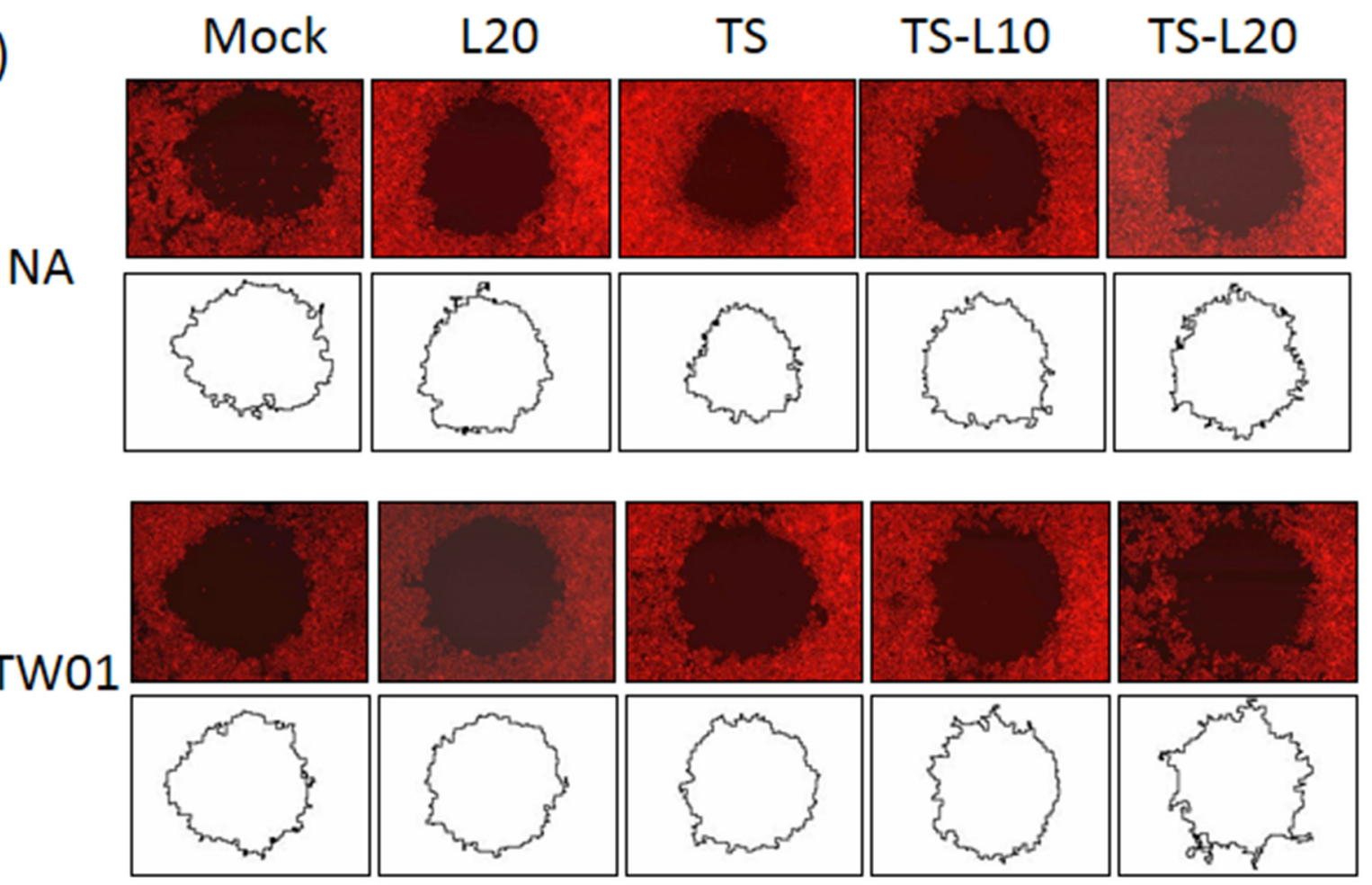

(b)

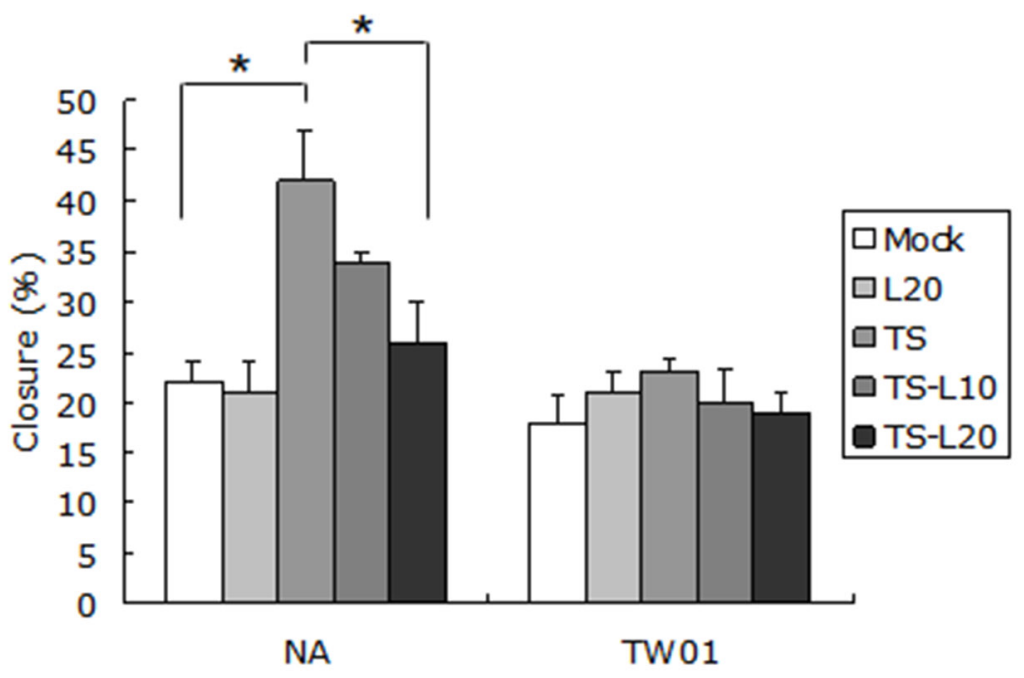

Figure 8: Luteolin represses reactivation-induced cell migration. a. NA and TW01 cells under repeated treatment were subjected to a cell migration assay, according to the protocol described in Material and Methods. The area of the cell-free zone was measured by Image J software. b. Cell migration was determined as percent closure and calculated as described in Materials and Methods. In all results, the values are a mean \pm SD from at least three separate experiments. *: $<<0.05$. L20: luteolin $20 \mu \mathrm{M}$; TS: TPA+SB; TS-L10: TPA+SB+luteolin $(10 \mu \mathrm{M})$; TS-L20: TPA+SB+luteolin $(20 \mu \mathrm{M})$. 
weeks of development for analysis of their growth. In NA-injected mice, we found tumor growth was enhanced after SB administration; however, this was inhibited by luteolin treatment (Figure 11d, left panel and 11e, upper panel). In addition, tumor growth in the SB-treated group was increased with NA cells, but not TW01 cells, at 28-day after SB treatment, compared to the mock control, suggesting EBV reactivation plays a causative role in the tumorigenisis of NPC cells in vivo (Figure 11e). Collectively, these results indicate that luteolin has a suppressive effect on NPC tumorigenesis in the mouse model by inhibition of EBV reactivation.

\section{DISCUSSION}

EBV has been associated with many human malignancies, although how it contributes to carcinogenesis is largely unknown [8]. The contribution of the lytic genes of EBV has been the most extensively studied in the etiology of EBV-induced posttransplant lymphoproliferative disorders (EBV-PTLD) after solid organ transplantation (reviewed in [58]). In the clinical course, a monoclonal tumor may develop after polyclonal B-cell proliferation [59]. The association of high rate malignant tumor occurrence with immunosuppression in renal homotransplantation was reported by TE Starzl after observation from 1962 to 1964 [60]. Subsequent reports corroborated this finding [61, 62]. Elevation of antibodies against EBV was found in patient sera [63] and EBV was detected in the oropharyngeal secretions [64]. Further studies indicated the disease may also be caused by EBV reinfection [65] or primary infection [66]. Treatment with acyclovir suppressed polyclonal B-cell proliferation [67] and PTLD [68], indicating that EBV reactivation plays an important role in these disorders. It was suggested that cytotoxic T cells against EBV-infected B cells were suppressed in renal transplant recipients after immunosuppression [69]. Withdrawal of immunosuppression was found to render the regression of PTLD, supporting the crucial role of cellular immunity in the development of PTLD [70]. With the development of EBV replication-defective mutants, in which the immediate early genes BZLF1 and BRLF1 were knocked out [71], it was possible to study the contribution of (a)
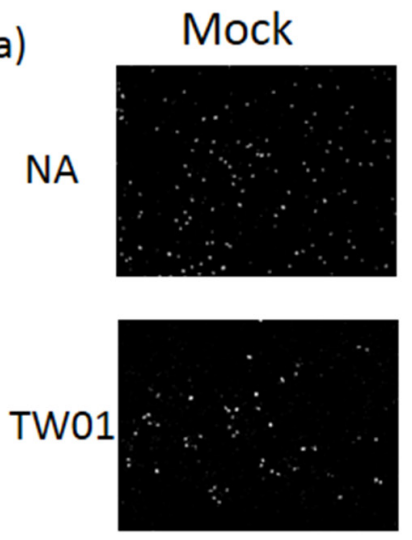
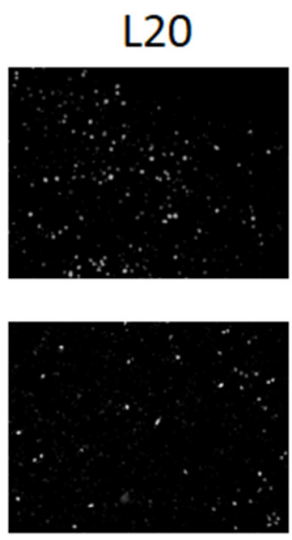

TS

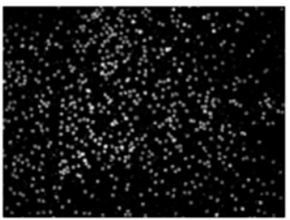

TS-L10
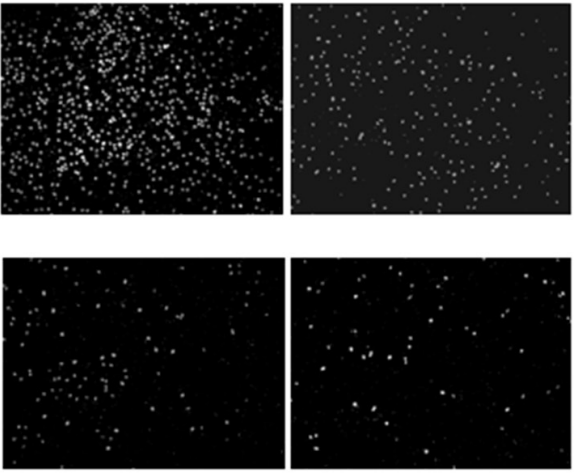

TS-L20
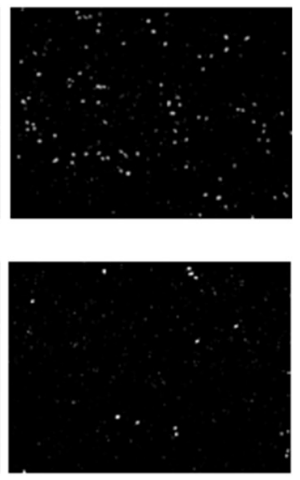

(b)

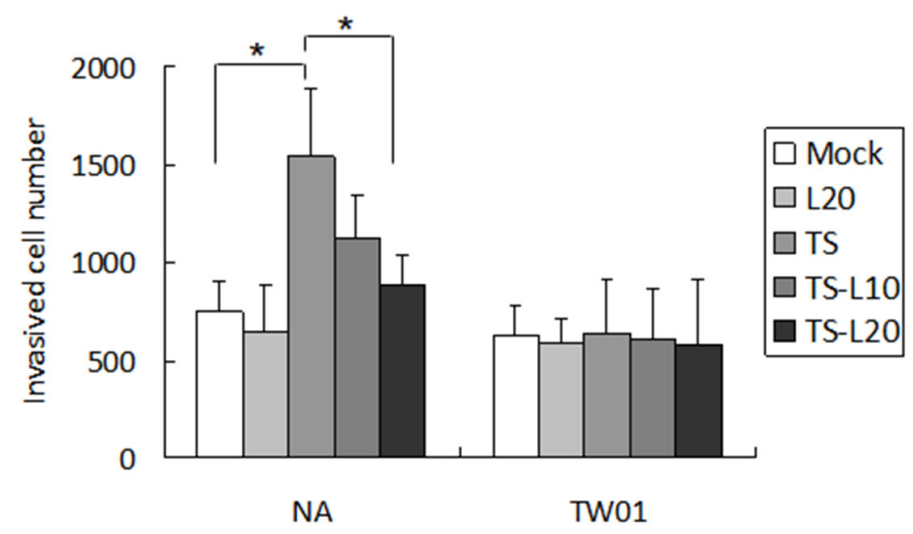

Figure 9: Luteolin represses reactivation-induced cell invasion. a. NA and b. TW01 cells under repeated treatment were subjected to a cell invasion assay, according to the protocol described in Material and Methods. In all results, the values are a mean \pm SD from at least three separate experiments. * ${ }^{*}$ < $<0.05$. L20: luteolin $20 \mu \mathrm{M}$; TS: TPA+SB; TS-L10: TPA+SB+luteolin $(10 \mu \mathrm{M})$; TS-L20: TPA+SB+luteolin $(20 \mu \mathrm{M})$. 
EBV lytic genes to the oncogenesis of PTLD. BZLF1 was shown to be important in the development of LCL tumors in SCID mice through induction of vascular endothelial growth factor (VEGF) [72]. BZLF1 also was found to enhance the tumor formation by BZLF1deleted LCL in SCID mice, through increased expression of IL-6 and IL-10 [73]. A humanized mouse model containing human CD34 cells (hematopoietic cells), thymus and liver tissues provided evidence that host cellular immunity contributes to the suppression of development of LPD [74]. Using superlytic (SL) mutants and OKT3 and anti-CD3 antibodies, a further study supported the contributions of EBV lytic infection and human cellular immunity to the development of LPC [75]. It was suggested that horizontal transmission of EBV may be important for PTLD formation and lytic EBV may contribute through paracrine effects and/or immunosuppression [74]. Similarly, reactivation of EBV was found to contribute to the tumorigenesis of NPC cells [38]. In this study, we wanted to determine whether reactivation of $\mathrm{EBV}$ can be a target in the management of NPC after remission.
For the contribution of lytic EBV genes to NPC tumorigenesis, we found chemical induced reactivation of EBV can promote genome instability and tumor formation in SCID mice $[38,56,76]$. In this study, we screened out the flavonoid luteolin as a viral inhibitor to block latent EBV entry into the lytic cycle. We demonstrated that appropriate doses of luteolin can inhibit the expression of EBV lytic proteins through repression of $\mathrm{Zp}$ and $\mathrm{Rp}$ activities (Figures 2-4), suggesting that luteolin is a promising agent for inhibiting the initial stage of latent EBV transition to lytic reactivation. Furthermore, we also found that luteolin treatment blocked the formation of MN and several tumorigenic properties of NPC cells (Figures 7-10). In a newly established mouse model, luteolin repressed reactivation-induced tumor formation (Figure 11), suggesting that luteolin can repress NPC tumorigenesis by inhibiting EBV reactivation.

"Antimicrobial adjuvant therapy" has been proposed recently to treat virus-related cancers and cancer-associated infections. Targeting cancerrelated viruses with antiviral agents is currently used in the treatment of hepatocellular carcinomas [77],

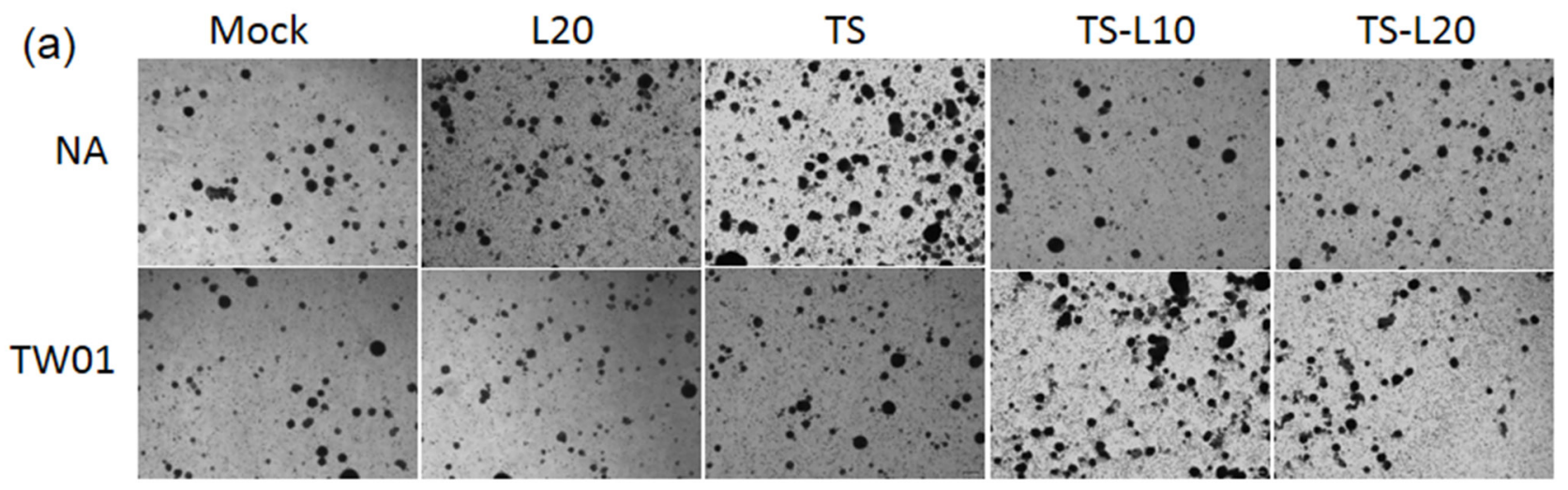

(b)

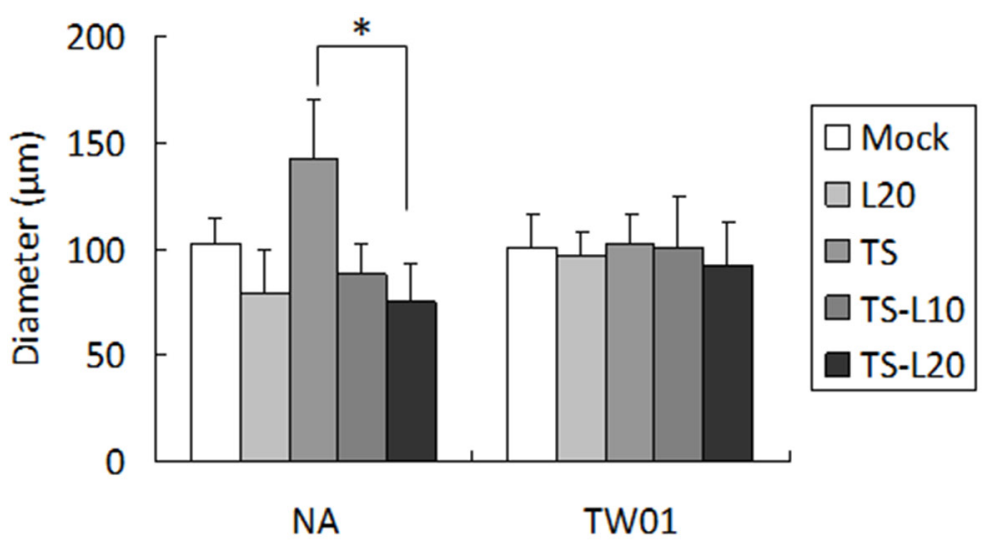

Figure 10: Luteolin represses reactivation-induced spheroid formation. a. NA and TW01 cells under repeated treatment were subjected to a spheroid assay, according to the protocol described in Material and Methods. $\mathbf{b}$. The diameter of the spheroids was measured from images captured by microscopy. In all results, the values are a mean $\pm \mathrm{SD}$ from at least three separate experiments. $*: \mathrm{p}<0.05$. L20: luteolin $20 \mu \mathrm{M}$; TS: TPA+SB; TS-L10: TPA+SB+luteolin $(10 \mu \mathrm{M})$; TS-L20: TPA+SB+luteolin $(20 \mu \mathrm{M})$. 
HHV8-associated cancers [78] and hematopoietic cancers [79], and this has yielded some compelling data to support their clinical use in combination with traditional therapies. Several anti-EBV or induction-lytic strategies have been proposed for the treatment of EBVrelated malignancies [80-91]. Based on our previous studies, the EBV lytic cycle was found to be crucial to the tumorigenesis of NPC cells and some lytic proteins

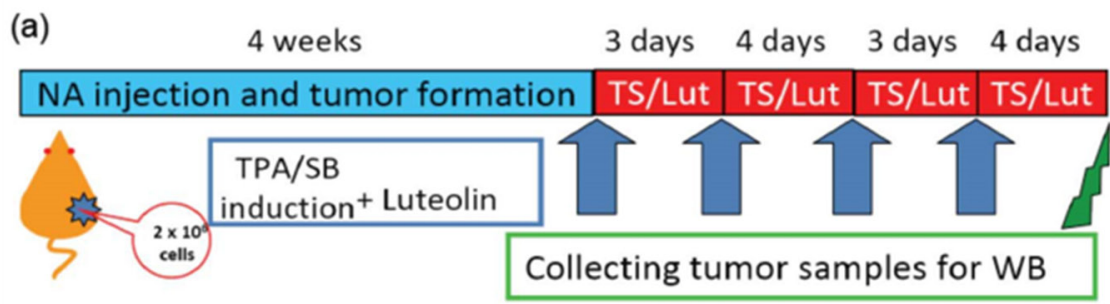

1.mock control.

2.0.6 mg/kg SB

$3.1 .2 \mathrm{mg} / \mathrm{kg} \mathrm{SB}$

4. mock control

$5.0 .6 \mathrm{mg} / \mathrm{kg}$ SB plus $1 \mathrm{mg} / \mathrm{kg}$ TPA

$6.0 .6 \mathrm{mg} / \mathrm{kg} \mathrm{SB}+1 \mathrm{mg} / \mathrm{kg}$ TPA +

$40 \mathrm{mg} / \mathrm{kg}$ of luteolin

$7.0 .6 \mathrm{mg} / \mathrm{kg} \mathrm{SB}$

$8.0 .6 \mathrm{mg} / \mathrm{kg} \mathrm{SB}+40 \mathrm{mg} / \mathrm{kg}$ of luteolin (b)

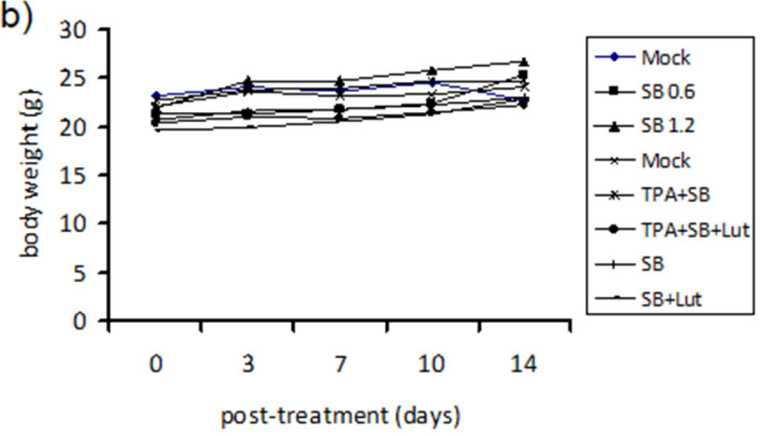

(C) Western analysis

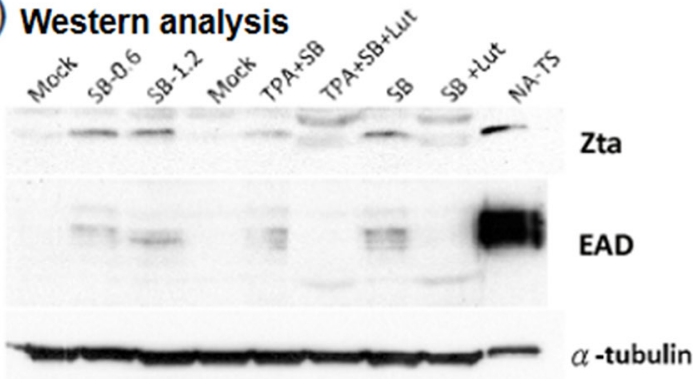

(d)

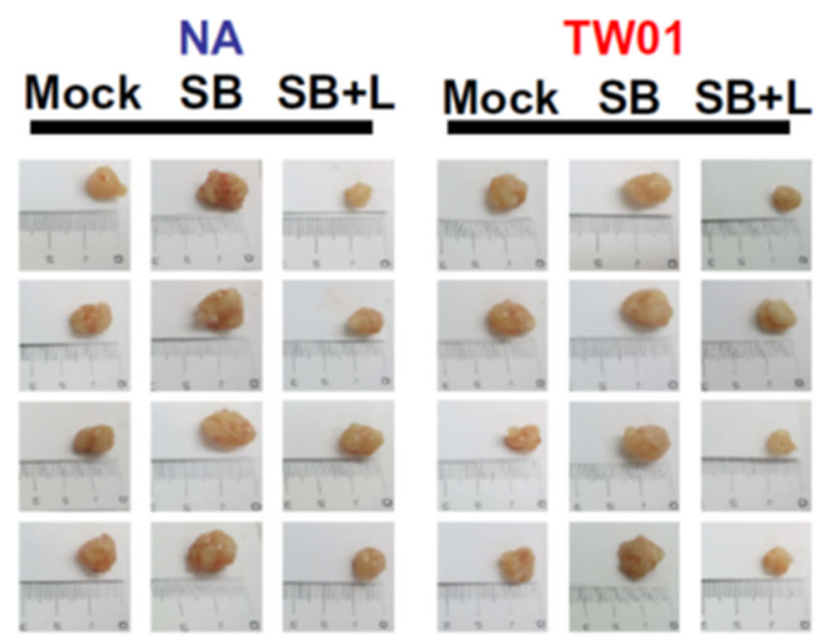

(e)
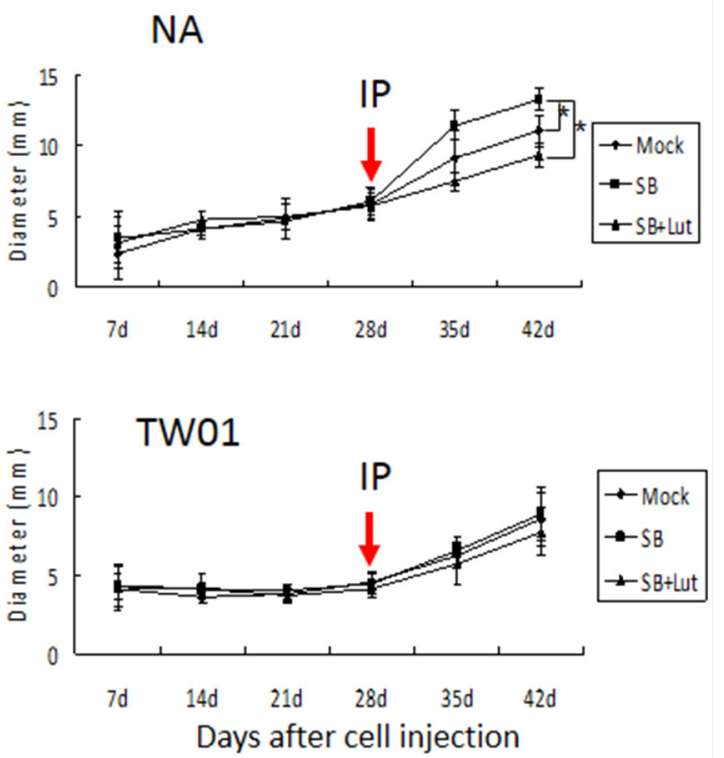

Figure 11: Inhibition of EBV reactivation by luteolin represses tumor growth in mouse model. NA cells were inoculated subcutaneously into SCID mice, which then received various treatments. a. Representative schedule of EBV reactivation inhibited by luteolin $\mathbf{b}$. The record of average animal body weights during the experiment $(n=3$ mice for each group) $(\longrightarrow-$ Mock: water injection; $\longrightarrow$ SB0.6: 0.6

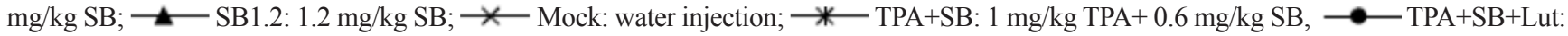
$1 \mathrm{mg} / \mathrm{kg}$ TPA+ $0.6 \mathrm{mg} / \mathrm{kg}$ SB plus $40 \mathrm{mg} / \mathrm{kg}$ luteolin; —— _ SB: $0.6 \mathrm{mg} / \mathrm{kg} \mathrm{SB}$; __ _ SB S Lut: $0.6 \mathrm{mg} / \mathrm{kg}$ SB plus $40 \mathrm{mg} / \mathrm{kg}$ luteolin) c. The expression of EBV lytic proteins in the tumors excised from the treated mice was analyzed by western blotting. d. Sacrificed mice and tumor nodules after excision were photographed at week 2. Mock: water injection; SB: $0.6 \mathrm{mg} / \mathrm{kg}$ of sodium butyrate injection; $\mathrm{SB}+\mathrm{L}: 0.6 \mathrm{mg} / \mathrm{kg}$ $\mathrm{SB}$ plus $40 \mathrm{mg} / \mathrm{kg}$ luteolin. e. The tumor diameter was measured weekly using callipers. Data are presented as mean $\pm \mathrm{SD}$. ( $\bullet-\mathrm{Mock}$ : water injection; - - SB: $0.6 \mathrm{mg} / \mathrm{kg}$ of SB injection; —- SB+Lut: $0.6 \mathrm{mg} / \mathrm{kg}$ SB plus $40 \mathrm{mg} / \mathrm{kg}$ luteolin) *: p $<0.05$ 
are known to have mutagenic or carcinogenic properties [38-41]. Taking EBV reactivation as an oncotarget, it is worth considering retarding or repressing the recurrence of NPC using natural products.

Luteolin is a flavonoid found in our diet, albeit in relatively low amounts $(<1 \mathrm{mg} /$ day $)$ [50, 52]. Epidemiological studies have revealed an inverse correlation between luteolin consumption and the risk of some cancers [92-95]. Furthermore, luteolin has been shown to have significant anti-carcinogenic effects through induction of anti-oxidation, anti-proliferation and apoptosis via multiple signaling pathways, in vitro and in vivo $[52,96]$. Luteolin has been shown to block Akt phosphorylation in TNF- $\alpha$ induced murine non-carcinoma intestinal epithelial cells [97]. Luteolin also has inhibitory effects in MAPK/ERK signaling and the PI3-K cascade $[98,99]$. In our laboratory, we found luteolin can repress phosphorylation of the ERK, p38, JNK and PKC pathways in NA cells (data not shown). Of note, blocking of the Akt, MAPK/ERK or PI3K pathways was shown to be important in preventing EBV reactivation [100, 101], suggesting inhibition of these signals by luteolin may contribute to its anti-viral and anti-cancer properties.

In investigating its modes of action, luteolin was found to cause significant inhibition of $\mathrm{Zp}$ and $\mathrm{Rp}$ activities (Figure 4). The mechanism is similar to EGCG and andrographolide, which also inhibit $\mathrm{Zp}$ and $\mathrm{Rp}$ activities $[102,103]$. On the contrary, curcumin and retinoid acid inhibit Zp [104] and moronic acid inhibits Rp activity [105]. In addition, SFN inhibits EBV reactivation by interfering with Rta transactivity [106]. Because Zp activation is the most important step in EBV reactivation in B cells, whereas Rp activation is critical in epithelial cells, compounds inhibiting both promoter activities, e.g. luteolin and EGCG, have better potential for clinical application. In addition, we found that luteolin blocks EBV reactivation by repressing the Zta and Rta promoter activities, disrupting Sp1 binding (data not shown). These functions will provide more potential for anti-cancer and anti-viral therapy.

In summary, we show that luteolin inhibits EBV reactivation by repressing the promoter activities of $\mathrm{Zp}$ and Rp. Furthermore, through inhibition of EBV reactivation, luteolin decreases viral reactivationinduced genomic instability and malignant features, such as cell proliferation, migration, invasion and spheroid formation. Luteolin also represses tumor growth in a mouse model. We propose here that EBV reactivation may be a novel target for prevention or retardation of NPC relapse and luteolin may provide a new solution to the drug-resistance problem and have potential as a lead for drug development. It also provides an alternative choice for antiviral therapy and prevention.

\section{MATERIALS AND METHODS}

\section{Compounds and antibodies}

Luteolin and the induction agents, 12-O-tetradecanoyl-phorbol-1,3-acetate (TPA) and sodium butyrate(SB), were purchased from SigmaAldrich Co. Antibodies used in this study include antiEBV Rta 467 (unpublished), anti-BMRF1 (EAD) 88A9 [107], anti-EBV Zta 4F10, anti-DNase 311H [108], anti$\beta$-actin (Sigma-Aldrich Co.) and anti-GAPDH (SigmaAldrich Co.).

\section{Cell lines}

TW01 is a human EBV-negative NPC cell line established from a Taiwanese NPC patient [36]. HONE-1 is another human EBV-negative NPC cell line, from a Chinese NPC patient [109]. NA and HA cells, are EBV converted cells obtained by co-culture of rAkata cells and TW01 and HONE-1 cells, respectively, and were selected by G418 (Sigma-Aldrich Co) treatment [35]. All of the above cell lines and their derivatives were maintained in DMEM (Dulbecco's modified Eagle's medium) supplemented with $10 \%$ fetal calf serum (FCS). C666-1 is a NPC cell lines derived from an NPC xenograft of southern Chinese origin [110]. It is maintained in RPMI-1640 supplemented with 5\% FCS.

\section{EBV induction by TPA plus SB and luteolin administration}

The EBV-positive NPC cell lines (NA and HA) were seeded for $24 \mathrm{hr}$ before carrying out the experiments. To determine whether luteolin can inhibit EBV reactivation, the cells were pre-treated for $1 \mathrm{hr}$ with various concentrations of luteolin. TPA $(40 \mathrm{ng} / \mathrm{ml})$ and SB $(3 \mathrm{mM})$ were added subsequently to co-treat to the cells for EBV induction. After 24 or $48 \mathrm{hr}$ incubation, the cells and their extracts were collected for further studies.

\section{Flow cytometric analysis}

To determine the number of cells which switched into the lytic cycle, cells were treated as indicated, harvested and fixed in 70\% ethanol. The fixed cells were permeabilized with $1 \%$ Triton X-100 and 4\% FBS and incubated with anti-EAD antibody (dilution 1:10) for 2 $\mathrm{hr}$ at room temperature. The cells were washed with PBS and incubated with a 1:1000 dilution of goat anti-mouse IgG rhodamine-conjugated antibody for $1 \mathrm{hr}$ and then washed and analyzed using a Becton Dickinson FACScan flow cytometer (BD Biosciences, San Jose, CA). Each experiment was in duplicate with 10,000 cells. 


\section{Transfection and analysis of luciferase reporter activity}

The construction of the $\mathrm{Zp}$ and $\mathrm{Rp}$ reporter plasmids has been described in previous reports [76, 106, 111]. $\mathrm{Zp}$ and $\mathrm{Rp}$ reporter plasmids were transfected using Lipofectamine 2000 (Invitrogen), according to the manufacturer's instructions. Briefly, NA or TW01 cells were seeded $\left(2 \times 10^{5} /\right.$ well) for $\mathrm{Zp}$ and $\mathrm{Rp}$ activation by TPA/SB. The $\mathrm{Zp}$ or $\mathrm{Rp}$ plasmid, mixed with Lipofectamine 2000 (Invitrogen) in Opti-MEM medium (Invitrogen), was incubated for $20 \mathrm{~min}$, then added to the culture wells containing the cells. After $3 \mathrm{hr}$ transfection, luteolin was added or not for pre-treatment for $1 \mathrm{hr}$, and then TPA $(40 \mathrm{ng} / \mathrm{ml})$ plus SB $(3 \mathrm{mM})$ or $\mathrm{SB}(3 \mathrm{mM})$ alone were added to induce EBV into the lytic cycle. After induction for $24 \mathrm{hr}$, the cells were lysed in $50 \mu \mathrm{l}$ HEPES buffer (0.1M HEPES, $\mathrm{pH} 7.8,1 \%$ Triton X-100, $1 \mathrm{mM} \mathrm{CaCl}_{2}$ and $1 \mathrm{mM} \mathrm{MgCl}$ ) and $25 \mu \mathrm{l}$ of the lysates were combined with $25 \mu$ of Luciferase Assay Reagent II (Promega) for 10 min incubation. Finally, the luciferase activity was measured using a luminescence counter (Packard). Each lysate sample was quantified for the expression of $\beta$-actin to control for variation in the amount of sample (data not shown). The mean and standard deviation of each sample were calculated from three independent experiments in duplicate.

\section{Determination of MN formation}

Detection of MN formation was carried out as described previously [24]. The cells under repeated treatment with inducers combined with or without luteolin were seeded onto coverslips to adhere. After $24 \mathrm{~h}$ incubation, the culture medium was removed and the cells were washed twice with phosphate-buffered saline (PBS, $\mathrm{pH} 7.4)$. The cells were fixed with ice-cold methanol for 15 min. After washing twice with PBS, the cells were stained with Hoechst. $(0.2 \mu \mathrm{g} / \mathrm{ml}$, Sigma-Aldrich, St. Louis, MO) for 15 minutes. Micronuclei were judged using a fluorescence microscope.

\section{Cell proliferation assay}

The cytotoxicity of luteolin to each cell line was determined by WST-1 assay (Invitrogen) according to manufacturer's instructions. Briefly, NA and TW01 cells $\left(5 \times 10^{3}\right.$ cells/well $)$ and HA and HONE- 1 cells $\left(1 \times 10^{4}\right.$ cells/well) were cultured in 96 well plates for $24 \mathrm{hr}$ and $48 \mathrm{hr}$. Various concentrations of luteolin $(0,1,5,10,20$, 50 and $100 \mu \mathrm{M}$ ) were incubated with the cells for 24 or $48 \mathrm{hr}$ and the cytotoxicity was analyzed by WST-1 assay. The fluorescence was measured with a microplate reader (Infinite M200, Tecan). The half maximum of cytotoxicity concentration $\left(\mathrm{CC}_{50}\right)$ was defined as the concentration of luteolin which killed $50 \%$ of the cells. The results of at least three independent experiments were used to calculate the mean and standard deviation.

\section{Cell migration assay}

Cell migration assays were carried out using the Oris system, according to the manufacturer's instructions (Platypus Technologies). Briefly, the cells were seeded in 96-well plates with Oris stoppers and then incubated for $24 \mathrm{hr}$. The stoppers were then removed and the cells were incubated for a further $24 \mathrm{hr}$ to permit cell migration. Finally, the cells were analyzed with PI staining and photographed by microscopy (Olympus). The closure of the cell-free zone was detected by Image $\mathrm{J}$ software (National Institute of Health). The cell migration was presented as the percentage of closure calculated using the following equation: [(pre-migration $)_{\text {area }}$-(migration $)_{\text {area }}$ ' (pre-migration $\left.)_{\text {area }}\right] \times 100$. The results of at least three independent experiments were used to calculate the mean and standard deviation.

\section{In vivo tumorigenesis model}

Six-week-old SCID mice were inoculated subcutaneously with NA cells $\left(2 \times 10^{6}\right.$ cells $)$ and examined over 4 weeks for tumor appearance. When the tumor size reached approximately $0.5 \mathrm{~cm}$ in diameter, the mice were separated into groups, each containing three mice. The $1^{\text {st }}$ group served as the control. The $2^{\text {nd }}, 3^{\text {rd }}$ and $4^{\text {th }}$ groups received $0.6,1.2 \mathrm{mg} / \mathrm{kg} \mathrm{SB}$ and $0.6 \mathrm{mg} / \mathrm{kg} \mathrm{SB}$ plus $1 \mathrm{mg} / \mathrm{kg}$ TPA, respectively, delivered by IP injection every 3 or 4 days. The $5^{\text {th }}$ and $6^{\text {th }}$ groups received $40 \mathrm{mg} / \mathrm{kg}$ of luteolin, delivered by IP injection every 3 or 4 days, before treatment with the inducers. Two weeks later, the animals were sacrificed and the tumors were excised and extracted to examine the expressions of EBV lytic proteins. For in vivo tumorigenesis assays, mice were inoculated subcutaneously with NA cells for 4 weeks and, when the tumor size reached approximately $0.5 \mathrm{~cm}$ in diameter, the mice were separated into three groups, each containing six mice. The $1^{\text {st }}$ group served as the control, the $2^{\text {nd }}$ group received $0.6 \mathrm{mg} / \mathrm{kg} \mathrm{SB}$, delivered by IP injection every 3 or 4 days, the $3^{\text {rd }}$ group received $40 \mathrm{mg} / \mathrm{kg}$ of luteolin, delivered by IP injection every 3 or 4 days, before the treatment with the inducers. The health of the mice and tumor sizes were monitored 3 or 4 days and the diameters of tumors were measured using calipers. Two weeks later, the animals were sacrificed and the tumors were excised for measurement and weighing.

\section{Spheroid assay}

Cells were seeded into non-coating $10 \mathrm{~cm}$-plates to maintain their suspension and incubated at $37^{\circ} \mathrm{C}$ for 7 days. After incubation, the spheroids sizes were photographed and their sizes determined using Image $\mathbf{J}$ software. 


\section{ACKNOWLEDGMENTS}

We thank Dr Tim J. Harrison (UCL Medical School, London, U.K.) for critical reviews and comments on the paper. We are deeply indebted to Dr. Kwok-Wai Lo (The Chinese University of Hong Kong, Hong Kong) for kindly providing us with C666-1 NPC cell lines. This work was supported partly by National Health Research Institutes and National Science Council, Taiwan (NSC993112-B-400-009, NSC101-2325-B-400-023, NSC1022325-B-400-021, NSC103-2325-B-400-008).

\section{CONFLICTS OF INTEREST}

There is no conflict of interest that I should disclose, having read the above statement.

\section{REFERENCES}

1. Parkin DM, Bray F, Ferlay J and Pisani P. Global cancer statistics, 2002. CA Cancer J Clin. 2005; 55:74-108.

2. Al-Sarraf M, LeBlanc M, Giri PG, Fu KK, Cooper J, Vuong T, Forastiere AA, Adams G, Sakr WA, Schuller DE and Ensley JF. Chemoradiotherapy versus radiotherapy in patients with advanced nasopharyngeal cancer: phase III randomized intergroup study 0099. J Clin Oncol. 1998; 16:1310-1317.

3. Lin JC, Jan JS, Hsu CY, Jiang RS and Wang WY. Outpatient weekly neoadjuvant chemotherapy followed by radiotherapy for advanced nasopharyngeal carcinoma: high complete response and low toxicity rates. Br J Cancer. 2003; 88:187-194.

4. Su SF, Han F, Zhao C, Huang Y, Chen CY, Xiao WW, Li JX and Lu TX. Treatment outcomes for different subgroups of nasopharyngeal carcinoma patients treated with intensitymodulated radiation therapy. Chin J Cancer. 30:565-573.

5. Lee AW, Foo W, Law SC, Peters LJ, Poon YF, Chappell R, Sze WM, Tung SY, Lau WH and Ho JH. Total biological effect on late reactive tissues following reirradiation for recurrent nasopharyngeal carcinoma. Int J Radiat Oncol Biol Phys. 2000; 46:865-872.

6. Murata T and Tsurumi T. Switching of EBV cycles between latent and lytic states. Rev Med Virol. 2014; 24:142-153.

7. Kenney SC and Mertz JE. Regulation of the latent-lytic switch in Epstein-Barr virus. Semin Cancer Biol. 2014; 26:60-68.

8. Rickinson $\mathrm{AB}$ and Kieff E. (2001). Epstein-Barr virus. In: Knipe DM and Howley PM, eds. Field's Virology. (Philadelphia: Lippincott Williams \& Wilkins), pp. 2575-2627.

9. de-The. (1982). Epidemiology of Epstein-Barr virus and associated disease in man. In: Roizman B, ed. The Herpesviruses I. (New York, London: Plenum.), pp. 25-103.

10. Crawford. (2004). Epstein-Barr virus. In: Zuckerman A, Banatvala J, JR P, Griffiths P and Schoub B, eds. Principles and Practice of Clinical Virology. (West Succex: John Wiley and Sons.), pp. 123-146.

11. Okano M, Thiele GM, Davis JR, Grierson HL and Purtilo DT. Epstein-Barr virus and human diseases: recent advances in diagnosis. Clin Microbiol Rev. 1988; 1:300-312.

12. Hildesheim A and Levine PH. Etiology of nasopharyngeal carcinoma: a review. Epidemiol Rev. 1993; 15:466-485.

13. McDermott AL, Dutt SN and Watkinson JC. The aetiology of nasopharyngeal carcinoma. Clin Otolaryngol Allied Sci. 2001; 26:82-92.

14. zur Hausen H, Schulte-Holthausen H, Klein G, Henle W, Henle G, Clifford P and Santesson L. EBV DNA in biopsies of Burkitt tumours and anaplastic carcinomas of the nasopharynx. Nature. 1970; 228:1056-1058.

15. Old LJ, Boyse EA, Oettgen HF, Harven ED, Geering G, Williamson B and Clifford P. Precipitating antibody in human serum to an antigen present in cultured burkitt's lymphoma cells. Proc Natl Acad Sci U S A. 1966; 56:1699-1704.

16. Henle $G$ and Henle W. Epstein-Barr virus-specific IgA serum antibodies as an outstanding feature of nasopharyngeal carcinoma. Int J Cancer. 1976; 17:1-7.

17. Chen JY, Chen CJ, Liu MY, Cho SM, Hsu MM, Lynn TC, Shieh T, Tu SM, Beasley RP, Hwang LY and et al. Antibody to Epstein-Barr virus-specific DNase as a marker for field survey of patients with nasopharyngeal carcinoma in Taiwan. J Med Virol. 1989; 27:269-273.

18. Chen JY, Hwang LY, Beasley RP, Chien CS and Yang CS. Antibody response to Epstein-Barr-virus-specific DNase in 13 patients with nasopharyngeal carcinoma in Taiwan: a retrospective study. J Med Virol. 1985; 16:99-105.

19. Chien YC, Chen JY, Liu MY, Yang HI, Hsu MM, Chen $\mathrm{CJ}$ and Yang CS. Serologic markers of Epstein-Barr virus infection and nasopharyngeal carcinoma in Taiwanese men. N Engl J Med. 2001; 345:1877-1882.

20. Zhu XX, Zeng Y and Wolf H. Detection of IgG and IgA antibodies to Epstein-Barr virus membrane antigen in sera from patients with nasopharyngeal carcinoma and from normal individuals. Int J Cancer. 1986; 37:689-691.

21. Ji MF, Wang DK, Yu YL, Guo YQ, Liang JS, Cheng WM, Zong YS, Chan KH, Ng SP, Wei WI, Chua DT, Sham JS and $\mathrm{Ng} \mathrm{MH}$. Sustained elevation of Epstein-Barr virus antibody levels preceding clinical onset of nasopharyngeal carcinoma. Br J Cancer. 2007; 96:623-630.

22. Cao SM, Liu Z, Jia WH, Huang QH, Liu Q, Guo X, Huang TB, Ye W and Hong MH. Fluctuations of Epstein-Barr virus serological antibodies and risk for nasopharyngeal carcinoma: a prospective screening study with a 20 -year follow-up. PLoS One. 2011; 6:e19100.

23. Young LS and Rickinson AB. Epstein-Barr virus: 40 years on. Nat Rev Cancer. 2004; 4:757-768.

24. Liu MT, Chen YR, Chen SC, Hu CY, Lin CS, Chang YT, Wang WB and Chen JY. Epstein-Barr virus latent membrane protein 1 induces micronucleus formation, 
represses DNA repair and enhances sensitivity to DNAdamaging agents in human epithelial cells. Oncogene. 2004; 23:2531-2539.

25. Liu MT, Chang YT, Chen SC, Chuang YC, Chen YR, Lin CS and Chen JY. Epstein-Barr virus latent membrane protein 1 represses p53-mediated DNA repair and transcriptional activity. Oncogene. 2005; 24:2635-2646.

26. Chen YR, Liu MT, Chang YT, Wu CC, Hu CY and Chen JY. Epstein-Barr virus latent membrane protein 1 represses DNA repair through the PI3K/Akt/FOXO3a pathway in human epithelial cells. J Virol. 2008; 82:8124-8137.

27. Zhang H, Tsao SW, Jin C, Strombeck B, Yuen PW, Kwong YL and Jin Y. Sequential cytogenetic and molecular cytogenetic characterization of an SV40T-immortalized nasopharyngeal cell line transformed by Epstein-Barr virus latent membrane protein-1 gene. Cancer Genet Cytogenet. 2004; 150:144-152.

28. Murono S, Inoue H, Tanabe T, Joab I, Yoshizaki T, Furukawa $\mathrm{M}$ and Pagano JS. Induction of cyclooxygenase-2 by Epstein-Barr virus latent membrane protein 1 is involved in vascular endothelial growth factor production in nasopharyngeal carcinoma cells. Proc Natl Acad Sci U S A. 2001; 98:6905-6910.

29. Yoshizaki T, Horikawa T, Qing-Chun R, Wakisaka N, Takeshita H, Sheen TS, Lee SY, Sato H and Furukawa M. Induction of interleukin- 8 by Epstein-Barr virus latent membrane protein-1 and its correlation to angiogenesis in nasopharyngeal carcinoma. Clin Cancer Res. 2001; 7:1946-1951.

30. Lu J, Chua HH, Chen SY, Chen JY and Tsai CH. Regulation of matrix metalloproteinase-1 by Epstein-Barr virus proteins. Cancer Res. 2003; 63:256-262.

31. Wakisaka N, Kondo S, Yoshizaki T, Murono S, Furukawa $\mathrm{M}$ and Pagano JS. Epstein-Barr virus latent membrane protein 1 induces synthesis of hypoxia-inducible factor 1 alpha. Mol Cell Biol. 2004; 24:5223-5234.

32. Kondo S, Seo SY, Yoshizaki T, Wakisaka N, Furukawa M, Joab I, Jang KL and Pagano JS. EBV latent membrane protein 1 up-regulates hypoxia-inducible factor 1alpha through Siahl-mediated down-regulation of prolyl hydroxylases 1 and 3 in nasopharyngeal epithelial cells. Cancer Res. 2006; 66:9870-9877.

33. Aga M, Bentz GL, Raffa S, Torrisi MR, Kondo S, Wakisaka N, Yoshizaki T, Pagano JS and Shackelford J. Exosomal HIF1alpha supports invasive potential of nasopharyngeal carcinoma-associated LMP1-positive exosomes. Oncogene. 2014; 33:4613-4622.

34. Yoshizaki T, Kondo S, Wakisaka N, Murono S, Endo K, Sugimoto H, Nakanishi S, Tsuji A and Ito M. Pathogenic role of Epstein-Barr virus latent membrane protein-1 in the development of nasopharyngeal carcinoma. Cancer Lett. 2013; 337:1-7.

35. Chang Y, Tung CH, Huang YT, Lu J, Chen JY and Tsai $\mathrm{CH}$. Requirement for cell-to-cell contact in Epstein-Barr virus infection of nasopharyngeal carcinoma cells and keratinocytes. J Virol. 1999; 73:8857-8866.

36. Lin CT, Wong CI, Chan WY, Tzung KW, Ho JK, Hsu MM and Chuang SM. Establishment and characterization of two nasopharyngeal carcinoma cell lines. Lab Invest. 1990; 62:713-724.

37. Hanahan D and Weinberg RA. Hallmarks of cancer: the next generation. Cell. 2011; 144:646-674.

38. Fang $\mathrm{CY}$, Lee $\mathrm{CH}, \mathrm{Wu} \mathrm{CC}$, Chang $\mathrm{YT}, \mathrm{Yu} \mathrm{SL}$, Chou SP, Huang PT, Chen CL, Hou JW, Chang Y, Tsai CH, Takada $\mathrm{K}$ and Chen JY. Recurrent chemical reactivations of EBV promotes genome instability and enhances tumor progression of nasopharyngeal carcinoma cells. Int $\mathrm{J}$ Cancer. 2009; 124:2016-2025.

39. Wu CC, Liu MT, Chang YT, Fang CY, Chou SP, Liao HW, Kuo KL, Hsu SL, Chen YR, Wang PW, Chen YL, Chuang HY, Lee CH, Chen M, Wayne Chang WS and Chen JY. Epstein-Barr virus DNase (BGLF5) induces genomic instability in human epithelial cells. Nucleic Acids Res. 2010; 38:1932-1949.

40. Chang YH, Lee CP, Su MT, Wang JT, Chen JY, Lin SF, Tsai CH, Hsieh MJ, Takada K and Chen MR. Epstein-Barr virus BGLF4 kinase retards cellular S-phase progression and induces chromosomal abnormality. PLoS One. 2012; 7:e39217.

41. Chiu SH, Wu CC, Fang CY, Yu SL, Hsu HY, Chow YH and Chen JY. Epstein-Barr virus BALF3 mediates genomic instability and progressive malignancy in nasopharyngeal carcinoma. Oncotarget 2014; 5:8583-8601. doi: 10.18632/ oncotarget. 2323.

42. Aggarwal BB and Shishodia S. Molecular targets of dietary agents for prevention and therapy of cancer. Biochem Pharmacol. 2006; 71:1397-1421.

43. Willett WC. Diet and health: what should we eat? Science. 1994; 264:532-537.

44. Chen TC and Holick MF. Vitamin D and prostate cancer prevention and treatment. Trends Endocrinol Metab. 2003; 14:423-430.

45. Siler U, Herzog A, Spitzer V, Seifert N, Denelavas A, Hunziker PB, Barella L, Hunziker W, Lein M, Goralczyk $\mathrm{R}$ and Wertz K. Lycopene effects on rat normal prostate and prostate tumor tissue. J Nutr. 2005; 135:2050S-2052S.

46. Tang L, Jin T, Zeng $X$ and Wang JS. Lycopene inhibits the growth of human androgen-independent prostate cancer cells in vitro and in BALB/c nude mice. J Nutr. 2005; 135:287-290.

47. McLaughlin F and La Thangue NB. Histone deacetylase inhibitors open new doors in cancer therapy. Biochem Pharmacol. 2004; 68:1139-1144.

48. Zeng Y, Ohshima H, Bouvier G, Roy P, Zhong J, Li B, Brouet I, de-The G and Bartsch H. Urinary excretion of nitrosamino acids and nitrate by inhabitants of high- and low-risk areas for nasopharyngeal carcinoma in southern China. Cancer Epidemiol Biomarkers Prev. 1993; 2:195-200. 
49. Lin Y, Shi R, Wang X and Shen HM. Luteolin, a flavonoid with potential for cancer prevention and therapy. Curr Cancer Drug Targets. 2008; 8:634-646.

50. Seelinger G, Merfort I, Wolfle U and Schempp CM. Anticarcinogenic effects of the flavonoid luteolin. Molecules. 2008; 13:2628-2651.

51. Seelinger G, Merfort I and Schempp CM. Anti-oxidant, anti-inflammatory and anti-allergic activities of luteolin. Planta Med. 2008; 74:1667-1677.

52. Lopez-Lazaro M. Distribution and biological activities of the flavonoid luteolin. Mini Rev Med Chem. 2009; 9:31-59.

53. Iwase $\mathrm{Y}$, Takemura $\mathrm{Y}, \mathrm{Ju}$-ichi M, Ito $\mathrm{C}$, Furukawa $\mathrm{H}$, Kawaii S, Yano M, Mou XY, Takayasu J, Tokuda H and Nishino $H$. Inhibitory effect of flavonoids from citrus plants on Epstein-Barr virus activation and twostage carcinogenesis of skin tumors. Cancer Lett. 2000; 154:101-105.

54. Mehla R, Bivalkar-Mehla S and Chauhan A. A flavonoid, luteolin, cripples HIV-1 by abrogation of tat function. PLoS One. 2011; 6:e27915.

55. Matsuo M, Sasaki N, Saga K and Kaneko T. Cytotoxicity of flavonoids toward cultured normal human cells. Biol Pharm Bull. 2005; 28:253-259.

56. Fang CY, Huang SY, Wu CC, Hsu HY, Chou SP, Tsai $\mathrm{CH}$, Chang $\mathrm{Y}$, Takada $\mathrm{K}$ and Chen JY. The synergistic effect of chemical carcinogens enhances Epstein-Barr virus reactivation and tumor progression of nasopharyngeal carcinoma cells. PLoS One. 2012; 7:e44810.

57. Fang CY, Wu CC, Hsu HY, Chuang HY, Huang SY, Tsai $\mathrm{CH}$, Chang Y, Tsao GS, Chen CL and Chen JY. EGCG inhibits proliferation, invasiveness and tumor growth by up-regulation of adhesion molecules, suppression of gelatinases activity, and induction of apoptosis in nasopharyngeal carcinoma cells. Int J Mol Sci. 2015; 16:2530-2558.

58. Paya CV, Fung JJ, Nalesnik MA, Kieff E, Green M, Gores G, Habermann TM, Wiesner PH, Swinnen JL, Woodle ES and Bromberg JS. Epstein-Barr virus-induced posttransplant lymphoproliferative disorders. ASTS/ASTP EBV-PTLD Task Force and The Mayo Clinic Organized International Consensus Development Meeting. Transplantation. 1999; 68:1517-1525.

59. Hanto DW, Sakamoto K, Purtilo DT, Simmons RL and Najarian JS. The Epstein-Barr virus in the pathogenesis of posttransplant lymphoproliferative disorders. Clinical, pathologic, and virologic correlation. Surgery. 1981; 90:204-213.

60. Murray JE, Wilson RE, Tilney NL, Merrill JP, Cooper WC, Birtch AG, Carpenter CB, Hager EB, Dammin GJ and Harrison JH. Five years' experience in renal transplantation with immunosuppressive drugs: survival, function, complications, and the role of lymphocyte depletion by thoracic duct fistula. Ann Surg. 1968; 168:416-435.
61. McKhann CF. Primary malignancy in patients undergoing immunosuppression for renal transplantation. Transplantation. 1969; 8:209-212.

62. Penn I, Hammond W, Brettschneider L and Starzl TE. Malignant lymphomas in transplantation patients. Transplant Proc. 1969; 1:106-112.

63. Spencer ES and Andersen HK. Antibodies to the EpsteinBarr virus in kidney transplant recipients. Acta Med Scand. 1972; 191:107-110.

64. Strauch B, Andrews LL, Siegel N and Miller G. Oropharyngeal excretion of Epstein-Barr virus by renal transplant recipients and other patients treated with immunosuppressive drugs. Lancet. 1974; 1:234-237.

65. Chang RS, Lewis JP, Reynolds RD, Sullivan MJ and Neuman J. Oropharyngeal excretion of Epstein-Barr virus by patients with lymphoproliferative disorders and by recipients of renal homografts. Ann Intern Med. 1978; 88:34-40.

66. Marker SC, Ascher NL, Kalis JM, Simmons RL, Najarian JS and Balfour HH, Jr. Epstein-Barr virus antibody responses and clinical illness in renal transplant recipients. Surgery. 1979; 85:433-440.

67. Darenkov IA, Marcarelli MA, Basadonna GP, Friedman AL, Lorber KM, Howe JG, Crouch J, Bia MJ, Kliger AS and Lorber MI. Reduced incidence of Epstein-Barr virusassociated posttransplant lymphoproliferative disorder using preemptive antiviral therapy. Transplantation. 1997; 64:848-852.

68. Hanto DW, Frizzera G, Gajl-Peczalska KJ, Sakamoto K, Purtilo DT, Balfour HH, Jr., Simmons RL and Najarian JS. Epstein-Barr virus-induced B-cell lymphoma after renal transplantation: acyclovir therapy and transition from polyclonal to monoclonal B-cell proliferation. N Engl J Med. 1982; 306:913-918.

69. Crawford DH, Edwards JM, Sweny P, Hoffbrand AV and Janossy G. Studies on long-term T-cell-mediated immunity to Epstein-B arr virus in immunosuppressed renal allograft recipients. Int J Cancer. 1981; 28:705-709.

70. Starzl TE, Nalesnik MA, Porter KA, Ho M, Iwatsuki S, Griffith BP, Rosenthal JT, Hakala TR, Shaw BW, Jr., Hardesty RL and et al. Reversibility of lymphomas and lymphoproliferative lesions developing under cyclosporinsteroid therapy. Lancet. 1984; 1:583-587.

71. Feederle R, Kost M, Baumann M, Janz A, Drouet E, Hammerschmidt W and Delecluse HJ. The Epstein-Barr virus lytic program is controlled by the co-operative functions of two transactivators. EMBO J. 2000; 19:3080-3089.

72. Hong GK, Kumar P, Wang L, Damania B, Gulley ML, Delecluse HJ, Polverini PJ and Kenney SC. Epstein-Barr virus lytic infection is required for efficient production of the angiogenesis factor vascular endothelial growth factor in lymphoblastoid cell lines. J Virol. 2005; 79:13984-13992. 
73. Hong GK, Gulley ML, Feng WH, Delecluse HJ, HolleyGuthrie E and Kenney SC. Epstein-Barr virus lytic infection contributes to lymphoproliferative disease in a SCID mouse model. J Virol. 2005; 79:13993-14003.

74. Ma SD, Hegde S, Young KH, Sullivan R, Rajesh D, Zhou Y, Jankowska-Gan E, Burlingham WJ, Sun X, Gulley ML, Tang W, Gumperz JE and Kenney SC. A new model of Epstein-Barr virus infection reveals an important role for early lytic viral protein expression in the development of lymphomas. J Virol. 2011; 85:165-177.

75. Ma SD, Yu X, Mertz JE, Gumperz JE, Reinheim E, Zhou Y, Tang W, Burlingham WJ, Gulley ML and Kenney SC. An Epstein-Barr virus (EBV) mutant with enhanced BZLF1 expression causes lymphomas with abortive lytic EBV infection in a humanized mouse model. J Virol. 2012; 86:7976-7987.

76. Huang SY, Fang CY, Tsai CH, Chang Y, Takada K, Hsu TY and Chen JY. N-methyl-N'-nitro-N-nitrosoguanidine induces and cooperates with 12-O-tetradecanoylphorbol1,3-acetate/sodium butyrate to enhance Epstein-Barr virus reactivation and genome instability in nasopharyngeal carcinoma cells. Chem Biol Interact. 2010; 188:623-634.

77. Papatheodoridis GV, Manolakopoulos S, Touloumi G, Vourli G, Raptopoulou-Gigi M, Vafiadis-Zoumbouli I, Vasiliadis T, Mimidis K, Gogos C, Ketikoglou I and Manesis EK. Virological suppression does not prevent the development of hepatocellular carcinoma in HBeAgnegative chronic hepatitis $\mathrm{B}$ patients with cirrhosis receiving oral antiviral(s) starting with lamivudine monotherapy: results of the nationwide HEPNET. Greece cohort study. Gut. 2011; 60:1109-1116.

78. Hengge UR, Ruzicka T, Tyring SK, Stuschke M, Roggendorf M, Schwartz RA and Seeber S. Update on Kaposi's sarcoma and other HHV8 associated diseases. Part 2: pathogenesis, Castleman's disease, and pleural effusion lymphoma. Lancet Infect Dis. 2002; 2:344-352.

79. Hermine O, Bouscary D, Gessain A, Turlure P, Leblond V, Franck N, Buzyn-Veil A, Rio B, Macintyre E, Dreyfus F and et al. Brief report: treatment of adult T-cell leukemialymphoma with zidovudine and interferon alfa. N Engl J Med. 1995; 332:1749-1751.

80. Slobod KS, Taylor GH, Sandlund JT, Furth P, Helton KJ and Sixbey JW. Epstein-Barr virus-targeted therapy for AIDS-related primary lymphoma of the central nervous system. Lancet. 2000; 356:1493-1494.

81. Kenney JL, Guinness ME, Curiel T and Lacy J. Antisense to the Epstein-Barr virus (EBV)-encoded latent membrane protein 1 (LMP-1) suppresses LMP-1 and bcl-2 expression and promotes apoptosis in EBV-immortalized B cells. Blood. 1998; 92:1721-1727.

82. Gutierrez MI, Judde JG, Magrath IT and Bhatia KG. Switching viral latency to viral lysis: a novel therapeutic approach for Epstein-Barr virus-associated neoplasia. Cancer Res. 1996; 56:969-972.
83. Oertel SH and Riess H. Antiviral treatment of EpsteinBarr virus-associated lymphoproliferations. Recent Results Cancer Res. 2002; 159:89-95.

84. Ghosh SK, Forman LW, Akinsheye I, Perrine SP and Faller DV. Short, discontinuous exposure to butyrate effectively sensitizes latently EBV-infected lymphoma cells to nucleoside analogue antiviral agents. Blood Cells Mol Dis. 2007; 38:57-65.

85. Westphal EM, Blackstock W, Feng W, Israel B and Kenney SC. Activation of lytic Epstein-Barr virus (EBV) infection by radiation and sodium butyrate in vitro and in vivo: a potential method for treating EBV-positive malignancies. Cancer Res. 2000; 60:5781-5788.

86. Mentzer SJ, Perrine SP and Faller DV. Epstein-Barr virus post-transplant lymphoproliferative disease and virusspecific therapy: pharmacological reactivation of viral target genes with arginine butyrate. Transpl Infect Dis. 2001; 3:177-185.

87. Perrine SP, Hermine O, Small T, Suarez F, O'Reilly R, Boulad F, Fingeroth J, Askin M, Levy A, Mentzer SJ, Di Nicola M, Gianni AM, Klein C, Horwitz S and Faller DV. A phase $1 / 2$ trial of arginine butyrate and ganciclovir in patients with Epstein-Barr virus-associated lymphoid malignancies. Blood. 2007; 109:2571-2578.

88. Feng WH, Israel B, Raab-Traub N, Busson P and Kenney SC. Chemotherapy induces lytic EBV replication and confers ganciclovir susceptibility to EBV-positive epithelial cell tumors. Cancer Res. 2002; 62:1920-1926.

89. Feng WH, Hong G, Delecluse HJ and Kenney SC. Lytic induction therapy for Epstein-Barr virus-positive B-cell lymphomas. J Virol. 2004; 78:1893-1902.

90. Hui KF, Ho DN, Tsang CM, Middeldorp JM, Tsao GS and Chiang AK. Activation of lytic cycle of Epstein-Barr virus by suberoylanilide hydroxamic acid leads to apoptosis and tumor growth suppression of nasopharyngeal carcinoma. Int J Cancer. 2012; 131:1930-1940.

91. Hui KF, Leung YY, Yeung PL, Middeldorp JM and Chiang AK. Combination of SAHA and bortezomib up-regulates CDKN2A and CDKN1A and induces apoptosis of EpsteinBarr virus-positive Wp-restricted Burkitt lymphoma and lymphoblastoid cell lines. Br J Haematol. 2013; 167:639-650.

92. Bosetti C, Spertini L, Parpinel M, Gnagnarella P, Lagiou P, Negri E, Franceschi S, Montella M, Peterson J, Dwyer J, Giacosa A and La Vecchia C. Flavonoids and breast cancer risk in Italy. Cancer Epidemiol Biomarkers Prev. 2005; 14:805-808.

93. Rossi M, Negri E, Talamini R, Bosetti C, Parpinel M, Gnagnarella P, Franceschi S, Dal Maso L, Montella M, Giacosa A and La Vecchia C. Flavonoids and colorectal cancer in Italy. Cancer Epidemiol Biomarkers Prev. 2006; 15:1555-1558.

94. Garcia-Closas R, Agudo A, Gonzalez CA and Riboli E. Intake of specific carotenoids and flavonoids and the risk 
of lung cancer in women in Barcelona, Spain. Nutr Cancer. 1998; 32:154-158.

95. Neuhouser ML. Dietary flavonoids and cancer risk: evidence from human population studies. Nutr Cancer. 2004; 50:1-7.

96. Pandurangan AK and Esa NM. Luteolin, a bioflavonoid inhibits colorectal cancer through modulation of multiple signaling pathways: a review. Asian Pac J Cancer Prev. 2014; 15:5501-5508.

97. Ruiz PA and Haller D. Functional diversity of flavonoids in the inhibition of the proinflammatory NF-kappaB, IRF, and Akt signaling pathways in murine intestinal epithelial cells. J Nutr. 2006; 136:664-671.

98. Agullo G, Gamet-Payrastre L, Manenti S, Viala C, Remesy C, Chap H and Payrastre B. Relationship between flavonoid structure and inhibition of phosphatidylinositol 3-kinase: a comparison with tyrosine kinase and protein kinase C inhibition. Biochem Pharmacol. 1997; 53:1649-1657.

99. Kim JH, Lee EO, Lee HJ, Ku JS, Lee MH, Yang DC and Kim SH. Caspase activation and extracellular signalregulated kinase/Akt inhibition were involved in luteolininduced apoptosis in Lewis lung carcinoma cells. Ann N Y Acad Sci. 2007; 1095:598-611.

100. Oussaief L, Hippocrate A, Ramirez V, Rampanou A, Zhang W, Meyers D, Cole P, Khelifa R and Joab I. Phosphatidylinositol 3-kinase/Akt pathway targets acetylation of Smad3 through Smad3/CREB-binding protein interaction: contribution to transforming growth factor beta1-induced Epstein-Barr virus reactivation. J Biol Chem. 2009; 284:23912-23924.

101. Liu S, Li H, Chen L, Yang L, Li L, Tao Y, Li W, Li Z, Liu H, Tang M, Bode AM, Dong Z and Cao Y. (-)-Epigallocatechin-3-gallate inhibition of Epstein-Barr virus spontaneous lytic infection involves ERK1/2 and PI3-K/Akt signaling in EBV-positive cells. Carcinogenesis. 2013; 34:627-637.

102. Chang LK, Wei TT, Chiu YF, Tung CP, Chuang JY, Hung SK, Li C and Liu ST. Inhibition of Epstein-Barr virus lytic cycle by (-)-epigallocatechin gallate. Biochem Biophys Res Commun. 2003; 301:1062-1068.
103. Lin TP, Chen SY, Duh PD, Chang LK and Liu YN. Inhibition of the Epstein-Barr virus lytic cycle by andrographolide. Biol Pharm Bull. 2008; 31:2018-2023.

104. Hergenhahn M, Soto U, Weninger A, Polack A, Hsu CH, Cheng AL and Rosl F. The chemopreventive compound curcumin is an efficient inhibitor of Epstein-Barr virus BZLF1 transcription in Raji DR-LUC cells. Mol Carcinog. 2002; 33:137-145.

105. Chang FR, Hsieh YC, Chang YF, Lee KH, Wu YC and Chang LK. Inhibition of the Epstein-Barr virus lytic cycle by moronic acid. Antiviral Res. 2010; 85:490-495.

106. Wu CC, Chuang HY, Lin CY, Chen YJ, Tsai WH, Fang CY, Huang SY, Chuang FY, Lin SF, Chang Y and Chen JY. Inhibition of Epstein-Barr virus reactivation in nasopharyngeal carcinoma cells by dietary sulforaphane. Mol Carcinog. 2013; 52:946-958.

107. Tsai $\mathrm{CH}$, Williams MV and Glaser R. Characterization of two monoclonal antibodies to Epstein-Barr virus diffuse early antigen which react to two different epitopes and have different biological function. J Virol Methods. 1991; 33:47-52.

108. Tsai CH, Liu MT, Chen MR, Lu J, Yang HL, Chen JY and Yang CS. Characterization of monoclonal antibodies to the Zta and DNase proteins of Epstein-Barr virus. J Biomed Sci. 1997; 4:69-77.

109. Glaser R, Zhang HY, Yao KT, Zhu HC, Wang FX, Li GY, Wen DS and Li YP. Two epithelial tumor cell lines (HNE-1 and HONE-1) latently infected with Epstein-Barr virus that were derived from nasopharyngeal carcinomas. Proc Natl Acad Sci U S A. 1989; 86:9524-9528.

110. Cheung ST, Huang DP, Hui AB, Lo KW, Ko CW, Tsang YS, Wong N, Whitney BM and Lee JC. Nasopharyngeal carcinoma cell line (C666-1) consistently harbouring Epstein-Barr virus. Int J Cancer. 1999; 83:121-126.

111. Tsai PF, Lin SJ, Weng PL, Tsai SC, Lin JH, Chou YC and Tsai CH. Interplay between PKCdelta and $\mathrm{Sp} 1$ on histone deacetylase inhibitor-mediated Epstein-Barr virus reactivation. J Virol. 2011; 85:2373-2385. 